\title{
SYSTEMATIC FIELD SURVEY ON LIMES TRANSALUTANUS. SĂPATA CASE
}

\begin{abstract}
Two adjoined forts and their surroundings, elements of the $3^{\text {rd }}$ century Roman frontier in Dacia - Limes Transalutanus, which were last archaeologically investigated in 1930, were recently systematic surface surveyed, resulting in the identification of the associated civilian settlement in what seemed, at first glance, as an unexpected location, more distant than other military vici the team had previously identified along the same frontier line.

Not only the limits of the settlement at Săpata were established, but also the density of occupation and territory division into various functional areas, allowing further interpretations regarding the network of ancient local roads and a better understanding of the way in which the Romans adjusted their built facilities to available resources (water) or exploited the strategical features of the relief.

Using an efficient, quick and rather inexpensive combination of survey methods (field walking and measurements of the magnetic susceptibility of the soil applied on a 4.8 ha surface, followed by pottery typological and spatial distribution analysis), the investigation team tried to mitigate the challenging vegetation situation, adjusting likewise to the limited resources of a scheduled research project. Data relevance was increased by applying statistical corrections and using complementary investigation methods in order to cover the various available types of land (relief, vegetation, visibility); while data integration was ensured employing a unitary spatial gridded system for fieldwork and also by relating the obtained results to the high resolution digital terrain model of the sites obtained during UAV photogrammetric aerial survey.

In particular, the study takes the opportunity opened by the analysis of the Roman Age pottery found in Săpata vicus to debate on the significance of the traditional, yet not unitary perceived, scholarly division between 'ChiliaMilitari' ware (dwelling on Dacian traditions) and Roman local production. The consistent percent of Chilia-Militari types in the collected lot and its uniform spatial distribution inside the civilian settlement raise questions about the potters' identity, their social status and reason to revive older production techniques.

Some data about a Middle Bronze Age settlement, belonging to Tei Culture, identified in the same surveyed area, are given also.
\end{abstract}

Keywords: fort, vicus, pottery, field walking, magnetic susceptibility

\section{INTRODUCTION}

eginning with the fall of 2014, we have been running a research project ${ }^{1}$ along Limes Transalutanus, south of Argeș River, on a $157 \mathrm{~km}$ long path. The project's aims were fully exposed in a previous paper,

\footnotetext{
${ }^{1}$ Granted by the Ministry of Education, through UEFISCDI, details at www.limes-transalutanus.ro.
}

\section{Eugen S. Teodor}

Romanian National History Museum, Bucharest esteo60@yahoo.co.uk

\section{Magdalena Ștefan}

Institute of Archaeology 'Vasile Pârvan', Bucharest National Museum of Eastern Carpathians, Sfântu Gheorghe

m_magdalena.stefan@yahoo.com

\section{Alexandru Bădescu}

Romanian National History Museum, Bucharest alex_bades@yahoo.com

DOI: $10.14795 /$ j.v4i 2.261

ISSN 2360 - 266X

ISSN-L 2360 - 266X 
more than two years ago, ${ }^{2}$ and will not be here reminded in detail. Nevertheless, we have to say that all the research undertaken prior to our action was almost exclusively oriented on the Roman forts and not on other elements of the Roman limes and also that, in general, the topographic information available in the beginning was of a precarious quality. ${ }^{3}$ Of course, developing frontier facilities has never been reduced to building just forts ${ }^{4}$, involving also the roads connecting the forts, a boundary line materialised in a manner everybody could understand, including barbarians, a network of turrets watching the border ${ }^{5}$, an alarming system, and logistic facilities (horrea, mansiones, stationes).

The civilian settlements related to limes Transalutanus, including the military vici, had never entered into the attention of Romanian archaeologists before our project. Without doubt, their study could enhance the limes understanding, as they came in existence 'symbiotically' with the military units, as providers of trade and craft services. ${ }^{6}$ The symbiosis means a mutual advantage, or, in other terms, a two ways conditioning. This relationship would have been even more powerful after the abolishing of the marriage's ban for the militaries, in the time of Septimius Severus. ${ }^{7}$ Such civilian settlements existing in the shadow of the forts gave not only a home for families, but provided militaries (and their families) the opportunity to increase their incomes and behave socially. ${ }^{8}$

Our project has crossed in the meantime two major stages. The first, taking mainly the year 2015, was dedicated to what we usually name the 'linear survey', as our playground is a frontier. This phase was meant to teach us 'something about everything', browsing each meter of the boundary's area, in order to mark relevant locations or to assess the state of conservation for each monument. At the end of this, we made a re-evaluation of our objectives for the next step. The second stage of research, done along the year 2016, was mainly about detailing data in some relevant but definite areas - a few forts and their outskirts (but not only). We changed at this point the priorities - as drawn in the initial project - from the 'less known' sites, to the 'most endangered' ones. As lengthy accounted in other place, ${ }^{9}$ most of the forts from Limes Transalutanus are systematically ploughed, although many of them are listed monuments in the national records. This is not the case for the forts known under the name of Săpata, but it is the case for their vicus. About the last we knew merely nothing until the last winter, when a volunteer of the project told us where the main civilian settlement. ${ }^{10}$ In the early spring the field

\footnotetext{
TEODOR/ȘTEFAN 2014, containing the necessary maps for orientation.

The only older monograph of this frontier we owe to Ioana BOGDAN CĂTĂNICIU (1997), in Romanian. See yet some general works about the Roman frontier system in Dacia (BOGDAN CĂTĂNICIU 1981; GUDEA 1997 , this last one having very serious mapping issues). See also the most recent overview for Limes Transalutanus (TEODOR 2015).

${ }_{4}$ KOOISTRA et alii 2013, 10.

5 TEODOR 2016b; TEODOR 2017.

SOMMER 1984, 51-52; BURNHAM/WACHTER, 1990, 7; ROGERS FLYNT 2005, 152-153.

CAMPBELL 1978, 159-162.

ROGERS FLYNT 2005, 156-157.

TEODOR 2016a.

${ }^{10}$ His name is Florin Chivoci, a high school teacher from Pitesti. The place of the volunteers in the research project was far more important than expected, an unplanned but welcomed resource in a low budget project (around 170,000
}

was ploughed and clear, recommending us to take urgent action; which we did.

\section{THE SITE}

Săpata is located in the northern third of the frontier which spans between Danube and Argeș River, 19 km southsoutheast of Pitești City, as the crow flies. It had entered the archaeological literature under this name in $19^{\text {th }}$ century, being then located on the territory of the village Săpata de Jos; after several administrative reforms, the site belongs now to the territory of Mârțești village, which in turn depends on the town hall of Săpăta. Nevertheless, the closest actual village is Lăngești, located immediately southeast to the monuments.

The forts were built in the angle made between the main stream of the area, Cotmeana, and a brook named Cetatea, spelled also 'Cetăţuia' (The /Small/ Fortress), at the end of a narrow terrace, narrowing even more north of the fortress, the only easy access to the plateau. The place was carefully chosen to provide a good natural defence, a common feature for the other Roman forts in the area (Izbăşeşti towards south and Albota towards northeast), mirroring a lack of boldness which is typical for the 'third century'. The adjoining valley from east is not deep (about $15 \mathrm{~m}$ ), but steep, mainly on the lower part of the slope, unusable for a siege (Figure 1). The western side of the hill is also steep, offering a good defensive position and a great visibility heading the main valley.

The safety came with a price: the forts are relatively far from the boundary line. This line is not known in front of the fort, only a segment of it being identified so far, located $2.3 \mathrm{~km}$ southeast, and another one at $3.7 \mathrm{~km}$ northeast. Those segments have different orientations, their joint being theoretically located at $1.7 \mathrm{~km}$ east of Săpata fort; an area not visible from the fort. ${ }^{11}$

The fortifications from Săpata have been known since the late $19^{\text {th }}$ century, when this frontier was first studied and described by Grigore Tocilescu - the main Romanian archaeologist of the time - and his topographer, Pamfil Polonic ${ }^{12}$. Their observations were collected in a larger paper published by Tocilescu in 1900 , but we know that all the work between Roşiori and Piteşti was done by Polonic alone. ${ }^{13}$ Pamfil Polonic was a trained topographer (with no formal studies in history) ${ }^{14}$, but we have good reasons to think Euros for three years). As one can see, the advantage was not strictly financial. 11 All three forts located north of Urlueni (Izbășești, Săpata, Albota), watching the frontier laid on a large opened plain, are built far away from the boundary (more than one $\mathrm{km}$ ), showing obviously a single design concept. The route of the frontier was planned mainly to be as short as possible, but for the permanent location of the garrisons the strongest natural defended places were chosen, a good compromise between both requirements being impossible. (TEODOR 2015, 104-110; TEODOR 2016d, esp. 31 with Fig. 2, 41 with Fig. 13, 47 with Fig. 22, 53 with Fig. 29). Note that for the southern sector of the frontier the 'rules' appear to had been different.

12 The line between Danube and the (small) city Roşiorii de Vede was previously seen and described by the German (young) archaeologist Carl SCHUCHHARDT (1885), but one wouldn't include this on the short list of relevant research. Before that one can mention 'antiquarian' research as those performed by August Treboniu Laurian or Cesar Bolliac (an account of the research previous to the Second WW at CANTACUZINO 1945, 445-451).

13 CANTACUZINO 1945, 447.

14 IUGA 1942. Polonic left also many notebooks, sketches and drawings, most of them unpublished. Its documentation about Limes Transalutanus became recently available (TEODOR 2015, 215-222 for notes; Fig. 4, 11, 13, 


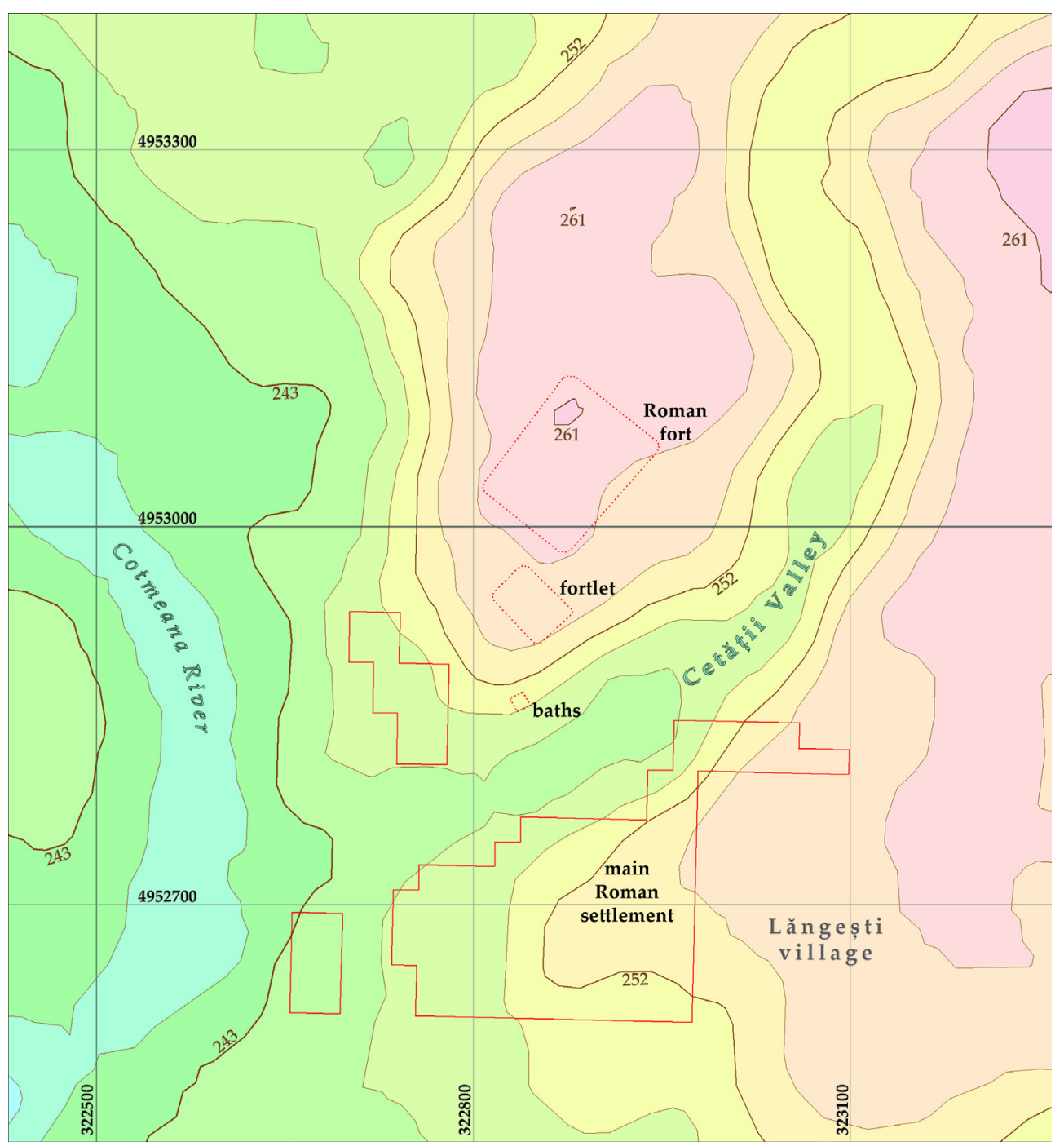

Fig. 1. Topographical outlook for the Roman monuments from Săpata, Argeş County. Red lines for the limits of the systematic survey.

UTM projection (metrical). Contours spaced at $3 \mathrm{~m}$, extracted from merged terrain models (Alos Palsar and Romanian 'numeric terrain' provided by ANCPI, resolution at $5 \mathrm{~m}$ ).

he had never used a theodolite ${ }^{15}$. A critical review of the outstanding! - work of the 'lieutenant' makes us understand that not the figures are relevant, but the main facts, due to his ability to see and represent things connected to anthropic changes of the landscape.

The plan published by Tocilescu (here Figure 2) contains several elements of interest. Two forts are represented, one larger, $120 \times 79.5 \mathrm{~m}$, and a smaller one, square, with the side of $45 \mathrm{~m},{ }^{16}$ with the same orientation

\section{$14,22,28,29,39$ are reproductions following Polonic's work)}

15 TEODOR 2015 is relying heavily on previously published and unpublished work of Pamfil Polonic, for its genuine value. For the errors in the general maps see TEODOR 2015, 42-43 (Fig. 13-14), 119-123. Comments about some errors in measurement are to be found everywhere along the book. The most relevant error is the layout of the fort from Crâmpoia, drawn with the length oriented west-east (TOCILESCU 1900, 126, Fig. 69), when, in fact, it is oriented north-south. This is giving us an inside of the methodology followed by Polonic, somehow similar with what Roman topographers did, measuring in the field, taking notes, but drawing in the office, following the notes. If the notes were wrong, or some data were missing, he had to improvise for a lucky guess...

16 Both published and unpublished sketches made by Polonic use 'paces' for lengths and meters for heights. A pace equals $0.75 \mathrm{~m}$, at least for Polonic. 'Pace' was and still it is used by the armies when there is no other mean to (which is the direction of the hill), north-northeast. The two are so close to each other that only $22 \mathrm{~m}$ separate their precincts, the ditch being common. The first ditch, running around both forts, is usually $15 \mathrm{~m}$ wide, except of the exposed long side of the larger fort ${ }^{17}$ where it measures an extra 3 meters. The ditch is strangely interrupted at the northern corner of the small fort. Two sides of the large fort, approximate a distance. For instance, NATO uses the equivalence 100 paces for $76 \mathrm{~m}$. For details see Teodor 2015, 19, with the note 9. It is obvious that Polonic handled this military practice from the same reason as the militaries. 17 The adjective 'larger' is here just a comparative one, in order to distinguish between the two forts. Similarly, the word 'fortlet', from the Figure 1, was chosen only for the sake of a shorter caption. In a strict typology, a 'fortlet' can have around 0.2 ha (or 50 x $40 \mathrm{~m}$ ), lacking principia (NAPOLI 1997, 239-240), but it can also be as large as 0.4 ha (BIDWELL/HODGSON, 1990, 47). Regarding the size of a fort, one could note that the large forts were common in the first century, the trend being towards a progressive shrinking of the dimensions, along the second and the third centuries (BIDWELL/HODGSON, 1990, 35). The large fort from Săpata, although having only around one hectare, is larger than the average size on Limes Transalutanus forts. This average small size of the forts is one of the clues of a late dating, in the third century. Anyway, a second statement is necessary: large standing forts are usually located in 'fertile and populous areas' (BIDWELL/HODGSON, 1990, 36), which is not the case for this frontier (strongly forested and in its initial stage of repopulation after almost two centuries of war). 


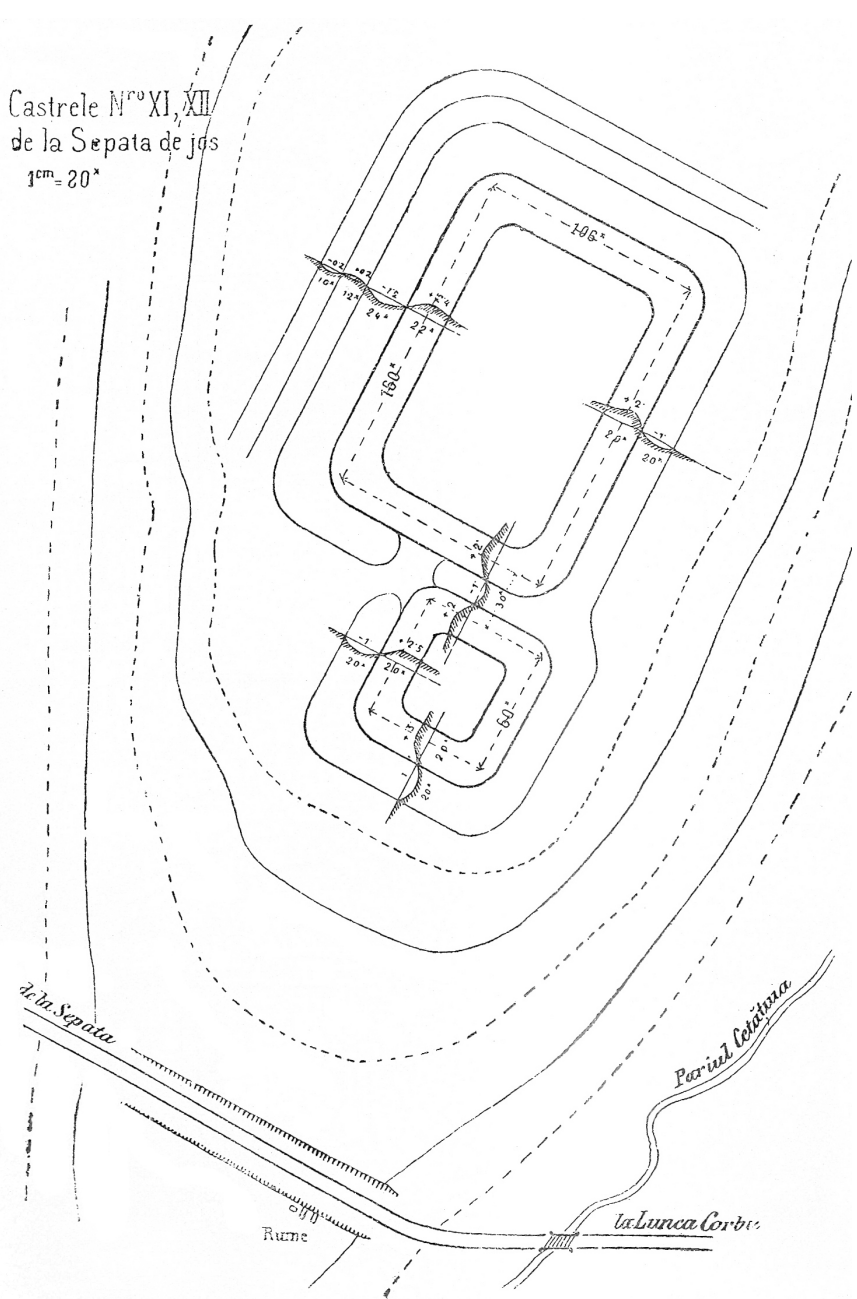

Fig. 2. Plan of the Roman forts from Săpata, as rendered by Pamfil Polonic and published by Grigore Tocilescu (1900, 133, fig. 76).

Please note the Romanian word "ruine" (ruins) at the bottom, south of the road.

exposed to the plateau from west and north, have a second ditch, $7.5 \mathrm{~m}$ wide.

But the most interesting detail of the plan from the Figure 2 is a small word, not very well printed, which is Rom. 'ruine' (ruins), which apparently never caught archaeologists' attention. Those ruins would be on the right hand of the Cetăţii Brook, $169 \mathrm{~m}$ south-southwest from the small fort, on the other side of the road connecting the villages Lunca Corbului and Săpata. Unfortunately, such a thing is impossible, as that road is made heading north, not west, as in the archaeological sketch. Older maps, as Szathmári Map (1864) and the Third Austrian Survey (published 1910, but containing data before 1900), prove that the road between Lunca Corbului and Săpata did not changed its track. ${ }^{18}$ Worst, the hollow way drawn by Polonic, west (north) of the bridge, cannot be located.

The only archaeological digging made at Săpata was done by Vasile Christescu in 1929-1930. The dimensions given for the forts were $125 \times 90 \mathrm{~m}$ and $45 \times 35 \mathrm{~m},{ }^{19}$ but no one should take the figures as granted, in a report for which the figures provided in text do not match the dimensions

\footnotetext{
${ }_{18}$ See also further on, Figures 5 or 17, for the orientation of the road between Lunca Corbului and Săpata.

19 CHRISTESCU 1938, 437, 441.
}

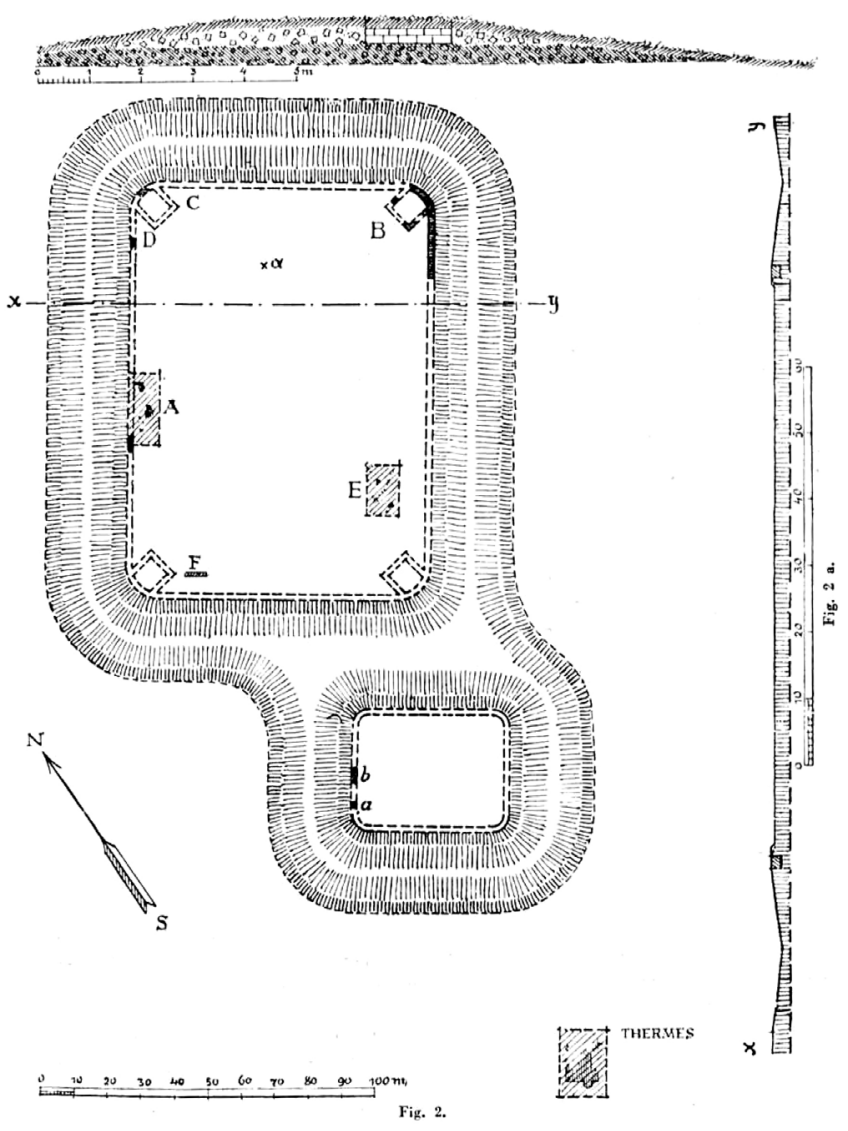

Fig. 3. Plan of the Roman forts from Săpata published by Vasile Christescu (1938, 436, Fig. 2).

from the plan (retaken here as Figure 3). The best example is the 'beast' tower from the eastern angle, measured with 'approximation' (own word) as stretching $10 \times 6 \mathrm{~m}$ at the inner side (sic), ${ }^{20}$ but depicted in the general plan as a rectangle of $8.25 \times 7.29 \mathrm{~m} .{ }^{21}$ In the same plan one can see a double ditch, one closing each fort, and a second closing both, which is a fantasy. The sketchy cross section published on the same page is representing yet one single ditch, but very large, about $23 \mathrm{~m}$ wide; in the textual description he was giving it as having $25 \mathrm{~m}$ in width and only $0.8 \mathrm{~m}$ deep, ${ }^{22}$ which is absurd, as we shall see.

The digging made by Vasile Christescu provided yet some usable news. He found a $200 \mathrm{~m}^{2}$ Roman baths, immediately south to the small fort, ${ }^{23}$ the first to be documented on Limes Transalutanus, and the only to date. ${ }^{24}$ The second good news was the hoard of 44 denarii, found in 'praetentura'25, coins minted between 205-242;

\footnotetext{
20 CHRISTESCU 1938, 439.

${ }^{21}$ Measurement in AutoCAD. Such dimensions for a tower in the early third century, within a fort of one hectare, are excluded. The Romanian archaeologists were not prepared in 1920s to deal with a 'prehistoric' site like this, with the brick wall spoiled by the villagers and missing completely for dozens of meters. He just couldn't understand what he was digging.

22 CHRISTESCU 1938, 436 with the Fig. $2 \mathrm{~b}$ for the cross-section; 439 for the width of the ditch. The ditch was not dug.

23 Located $40 \mathrm{~m}$ away, in the descriptive text (CHRISTESCU 1938, 441), but $62 \mathrm{~m}$ on the plan.

${ }_{24}$ Two others are known at Voinești and Rucăr, but both are dated in the early second century, before the idea of limes (as a military frontier) was born. 25 There are no means to determine which that is, but Christescu meant the north-eastern part.
} 


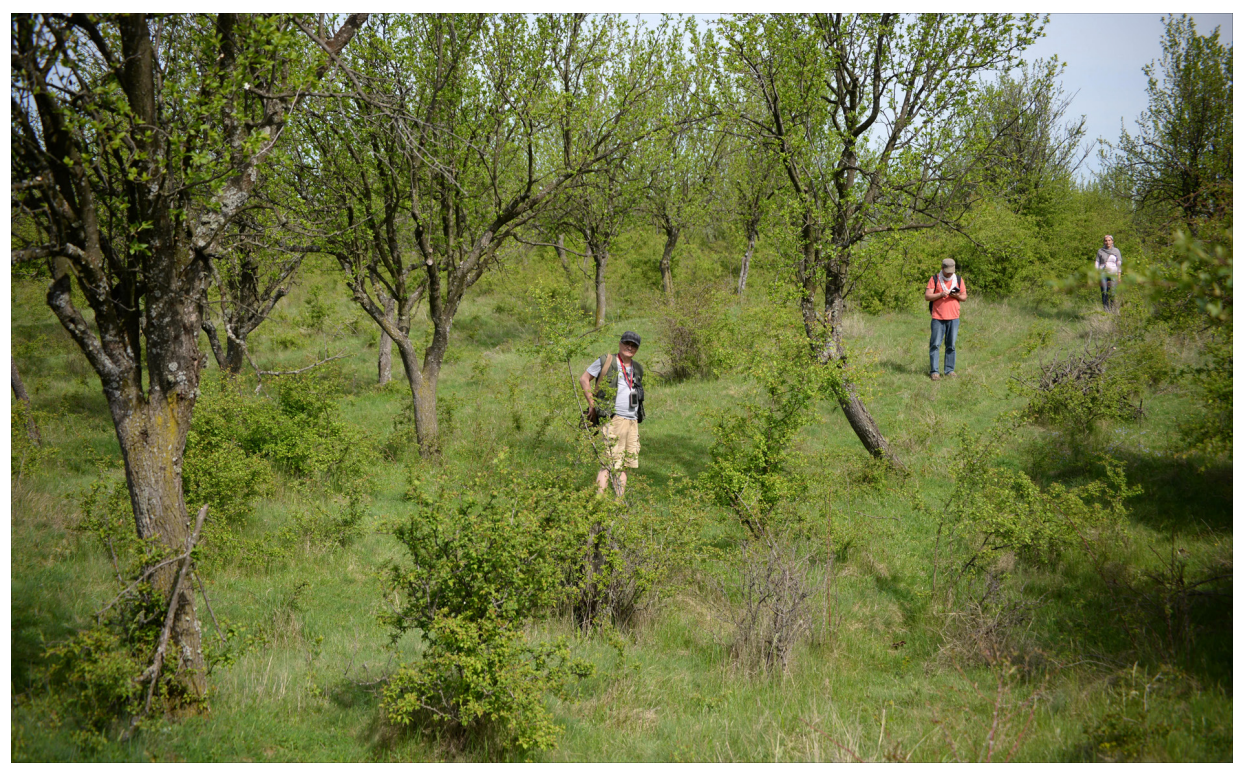

Figure 4. Human scale for the outer escarp of the large fort's ditch on the north-eastern side (April 2016). results were inconclusive, due to the mentioned vegetation conditions.

The surprise came in the early spring 2016, when a collaborator wrote to inform us that he had found the vicus. The location was a surprise, because he pinpointed the opposite, southern bank of the Cetăţii Valley ${ }^{29}$. In the beginning of April we went there to check the information, which proved valid. More than that, most of the plots were freshly ploughed, the visibility was average good and thus we decided to plan a systematic survey for the mid April.

\section{METHODOLOGY}

Fieldwalking is a basic there have been found also 11 coins as stray finds, dated between Commodus and Gordian (III), last issued in 242, date considered by the author as the end of the large fort. ${ }^{26}$ This discovery drove the archaeologist to think that Limes Transalutanus functioned between 205 and 242, which is not far from the first proposed chronology, and close to the present day rationale. ${ }^{27}$

From those days the site has changed a lot. Christescu was describing it as ploughing land. Today, the whole hill is covered by a plum orchard, planted almost half a century ago, nowadays old and completely neglected for many years. On the occasion of settling the orchard, deep ploughing was practiced between the trees' rows, affecting the archaeological site; now it is just a sort of cultivated forest, invaded by spiky bushes and tall grasses, with low visibility (Figure 4). The edges of the hill, where steep slopes occur, are obscured by curtains of wild trees and high bushes. Arable field today lies at the terrace's foothill, in northwest, but that is a bit too far from the forts. A small parcel of ploughing land appears between the hill and the road, measuring 145 x $42 \mathrm{~m}$, and that was the only place were hints for a civilian settlement were obvious from the beginning. ${ }^{28}$ In the opposite side of the road another arable land is located, still with a very low visibility. We made a thorough research of the entire upper plateau, mainly outside the forts, in order to locate other traces of the civilian settlement, but the

\footnotetext{
26 Interesting to note, most of the stray coins were minted in the time of Alexander Severus (222-235), which is not a usual distribution of the coinage in southern Romania. The distribution of the hoard is yet quite different: 2 Septimius Severus, 3 Elagabalus, 10 Al. Severus, 2 Maximinus, 27 Gordian (CHRISTESCU 1934). In what concerns the ending date of the hoard from Săpata (242), it is not directly relevant, the hoard being buried in the same horizon with other 6 hoards, ending in the early rule of Philippus Arabs, in 245 (PETAC 2011, 30; DIMA 2012, 139), giving a more accurate date for the end of this limes.

27 CHRISTESCU 1934, 75; TOCILESCU 1900, 122, for the construction time of Limes Transalutanus; PETOLESCU 2010, 184-188, for a later date of the foundation of Limes Transalutanus, in the time of Caracalla.

28 That plot is near the supposed location of the 'ruins' mentioned by Tocilescu.
}

technique for assessing the archaeological content of a site, being cheap, fast and non-destructive, ${ }^{30}$ as an instrument associated to the larger domain of landscape archaeology, at least in the recent decades. The methodological options are apparently countless (in transects or grids, collecting/not collecting, weighting or not, etc.), but the operational options will be driven by some a priori conditions, like: the size of the territory under investigation, the main purpose of the quest (e.g. a loose demographic estimation on larger surfaces vs. an intra-site density evaluation), the level of the knowledge prior to the action, the size and qualification of the team, and, last but not least, the financial support. ${ }^{31}$ Fieldwalking is usually associated to other means of investigation, like cartography and toponymy, aerial reconnaissance, photogrammetry, geophysics, geochemistry, statistics. ${ }^{32}$ All the means used within the research would be ideally joined in a cross reference system, providing comparative data. In our case, a complete survey of the site with concurrent means was not possible, as we shall see, making us choose a complementary perspective.

Travelling through western Muntenia - the actual province laying east of the Lower Olt River - one can meet two basic types of field systems: huge fields, comprising a unique, compact property (or association of land owners), stretching kilometres around, a type of modern agricultural venture, of recent formation, but in statistical minority; very fragmented propriety, the stripes of land being relatively long, but as narrow as $10 \mathrm{~m}$ or less. From an archaeological point of view, the first has clear advantages, from at least

\footnotetext{
9 A surprise because the usual territorial relationship between a fort and its vicus is very close, not on the other bank of a river (BURNHAM/WACHTER, 1990, 7; example as Little Chester, pp. 220-225; BIDWELL/HODGSON, 1990 , 75-77, Slack, West Yorks; idem, pp. 88-90, for Little Chester), although exceptions occur (BURNHAM/WACHTER, 1990, 208-211, Charterhouse, where the vicus is located $300 \mathrm{~m}$ from the fort; York, with the military settlement becoming a colonia, very close to porta praetoria, about $100 \mathrm{~m}$, but on the opposite side of the river Ouse, see BIDWELL/HODGSON, 1990, 77-78).

30 Grossly non-destructive (TARTARON 2003, 26, note 32).

EVANS REES 2013

TARTARON 2003, 43-45
} 
three reasons: first, because there are large fields with the same culture, in the same stage of the crop, allowing a good observation aerial survey, within the same conditions; secondly, because the same even conditions are met in the fieldwalk, giving comparable results; thirdly, because if something is to be negotiated, one have to get a deal with only one person, not with dozens.

The agricultural lands around the Roman forts from Săpata fall in the second category, although the average widths of the strips of land are over $20 \mathrm{~m}$. In our advantage was yet the similar stage of works, for most of the properties within the area of interest. This is why we have decided to try a systematic field survey. In this respect, a unique grid was projected, covering all the land around the fortresses, covering a rectangle of $840 \times 680 \mathrm{~m}$, oriented with the length north-south, with the origin point in northwest. ${ }^{33}$ The main unit of the grid is a $40 \mathrm{~m}$ square, noted with letters heading south and with numbers heading east, having names like A01 (first) or U17 (last). Due to the fragmented land property, those $40 \mathrm{~m}$ squares could be too large to be handled right, so each square of the main grid was divided in four squares of $20 \times 20 \mathrm{~m}$, named after the geographical directions (NW, NE, SW, SE). The data and the artefacts were collected under those small squares, named like L09-NW or R10-SE.

Small sized artefacts, like pottery sherds or flints, were meant to be collected and processed in the laboratory. The large and heavy artefacts, like the bricks, were gathered and weighed, for each grid sub-units, then discarded on the spot. Some of the artefacts, yet, like the pebbles or the burned adobe ${ }^{34}$, couldn't be gathered or weighed, therefore we needed a relative scale of estimation, as follows:

Table 1. Estimation of the frequencies

\begin{tabular}{ll}
\hline code & \multicolumn{1}{c}{ meaning } \\
\hline 5 & very much (one cannot step without touching the artefacts) \\
\hline 4 & $\begin{array}{l}\text { much, but not meeting the condition from above, } \\
\text { eventually in large pieces }\end{array}$ \\
\hline 3 & much, as above, but rather small size objects \\
\hline 2 & less frequent, difficult to see, but more than one object \\
\hline 1 & only one piece of evidence for $400 \mathrm{~m}^{2}$ \\
\hline 0 & null \\
\hline
\end{tabular}

Because the stage of culture was generally similar, but not identical across the field, we also needed a scale of the visibility:

\footnotetext{
33 Point location: Stereo70: 481168.117356880 .120 (Lat/Lon: $44.71174526^{\circ}$ $\left.\mathrm{N}, 24.76232155^{\circ} \mathrm{E}\right)$.

34 The local geology is of course important. All Romanian Plain is a huge deposit of clay, from 20 to $100 \mathrm{~m}$ deep. There are no rocks (in a non-geologic meaning), of no sort, but river pebbles, due to remote geological ages, organized in layers located at diverse depths, from $10 \mathrm{~m}$ in south to $2 \mathrm{~m}$ in north of the plain, as a general rule (with exceptions). This is why all the Roman forts were made of logs and adobe, when not bricks (as the large fort from Săpata), as well as the vernacular architecture till the $20^{\text {th }}$ century. The initial survey on the site showed that one can find on the field large quantities of burned adobe.
}

Table 2. Scale of the visibility in the field

\begin{tabular}{ll}
\hline code & \multicolumn{1}{c}{ meaning } \\
\hline 5 & ploughed and freshly harrowed \\
\hline 4 & $\begin{array}{l}\text { ploughed, but not freshly harrowed, or not harrowed at all } \\
\text { (or a similar disadvantage) }\end{array}$ \\
\hline 3 & $\begin{array}{l}\text { small sized culture (under } 10 \mathrm{~cm} \text { ), not very dense, relatively } \\
\text { good conditions of observation }\end{array}$ \\
\hline 2 & $\begin{array}{l}\text { relatively small culture (under } 20 \mathrm{~cm} \text { tall), relatively dense, } \\
\text { restricted visibility }\end{array}$ \\
\hline 1 & $\begin{array}{l}\text { relatively tall culture, but with visible soil (like the corn), the } \\
\text { search of artefacts is possible, but difficult }\end{array}$ \\
\hline 0 & null visibility, observation not available \\
\hline
\end{tabular}

As not all the square units of $20 \times 20$ were integrally available for research, the file of each contained also its availability, in percent, which is a correction factor for the final results of statistics. ${ }^{35}$

The grid was materialised in the field using yellow plastic cones, $40 \mathrm{~cm}$ tall, using a handheld GPS ${ }^{36}$. Of course, a total station would be much more exact, but also slower and asking for supplementary manpower. These are the kind of decisions a small budget project has to take.

From the early stages of work in the field it became obvious that we are not dealing with a simple archaeological site, containing only one layer of anthropic depositions, but with at least two: a Roman Age settlement, and a Bronze Age settlement, fact which made things more complicated. Even worse, some of the observations in the field, like the frequency of the burned adobe, became more difficult to asses.

\section{ROMAN AGE POTTERY}

The systematic survey of the Roman settlement at Săpata took place during 15-16 April 2016, being carried on at the site by Eugen S. Teodor, Magdalena Ștefan and Mihai Florea, from the main team of the project, Dragoș Măndescu and Ion Dumitrescu, archaeologists from the Argeș County Museum, and the volunteers Raluca Bătrânoiu (PhD student at the University Bucharest), Andi Pițigoi, Florin Chivoci (Pitești), and Mihai Micu (Bucharest). All available surfaces west of the forts, on the both parts of the Cetății Valley, were surveyed on the occasion, as it was all the land laying south of the same valley. The total investigated area measures 4.88 hectares. Collected artefacts were processed in the next two months or so, analysis performed by Eugen S. Teodor and Alexandru Bădescu.

The results are presented in Figure 5, based mainly on pottery, with shades of grey progressively darker for a lot of pottery. The frequency of the pottery was calculated based on the total weight of the sherds collected in a grid unit, and not on the number of sherds. To that figure corrections for visibility and availability were applied ${ }^{37}$. The general

35 As a whitish cover over the field (dry saline soils); simply: well but far from perfect.

36 The usual error for this generation of GPS (Garmin Montana 650) is 2-3 $\mathrm{m}$. For short durations of time, as positioning 9 corner signs (10 minutes), the error tend to have the same direction, a fact which relativize the error.

37 The calculation formula is $\mathrm{W}^{*}(100 / \mathrm{A})^{\star}(5 / \mathrm{V})$, where $\mathrm{W}=$ weight (per grid 


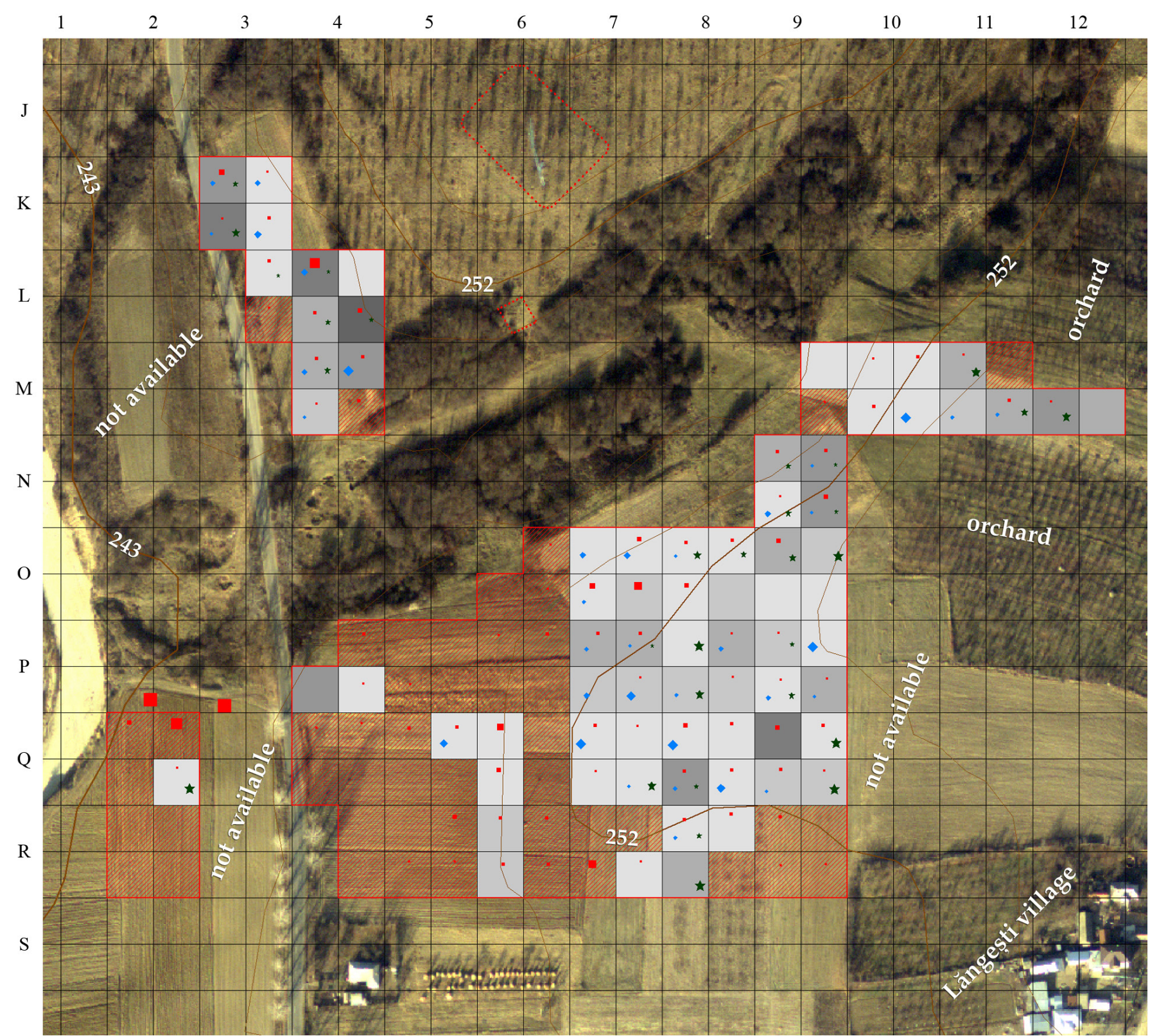

Fig. 5. Results of the systematic survey in the Roman settlement.

Red hatches - no pottery; grey surfaces - progressive scale for Roman Age pottery, from a few (light shades) to many (dark shades); diamonds progressive scale of imported pottery (larger if many); stars - progressive scale of Chilia Militari type (larger if many); red squares - Roman bricks (larger for many); 20 m square grid; military orthophoto 2012; Stereographic projection (datum Dealul Piscului 1970).

density of artefacts is nowhere great, the best result being 1181 grams of Roman Age pottery for a surface of $400 \mathrm{~m}^{2}$. We cannot compare this result with the forts themselves, because they are not available for survey, but we can compare results with other sites from the same limes. The civilian settlement from Săpata is located in an average position on a density graph , being higher than those documented for the sites at Putineiu, Băneasa or Crâmpoia, but inferior to those at Valea Urlui or Urlueni. ${ }^{38}$

The studied sherds (counting 616) were classified in 61 fabrication types, too many to be discussed in detail unit, grams), $\mathrm{A}$ = availability (percent), $\mathrm{V}$ = visibility (as in the Table 2).

38 Not yet published results, but shortly mentioned in the Archaeological Report sent for CCA (Cronica Cercetărilor Arheologice din România), expected to become available in print in May 2017. See also the Interim report for the year 2016, published on the project's website (http://www.limestransalutanus.ro/rapoarte/raport etapa3.html, section 4). here $^{39}$. Those types can be grouped yet in the next general classes of fabrication.

In the Table 3 one can see the prevalence of the coarse pottery for Bronze Age, the predominance of the half-fine

Table 3. Distribution of the fabrication types in classes of fabrication

\begin{tabular}{lcccc}
\hline Age, culture & fine & half-fine & coarse & $\begin{array}{c}\text { very } \\
\text { coarse }\end{array}$ \\
\hline Bronze Age & 2 & 4 & 6 & 1 \\
\hline Chilia-Militari & 1 & 8 & 4 & \\
\hline Roman & 1 & 11 & 5 & 1 \\
\hline Imports & 8 & 6 & 1 & \\
\hline Middle Age & & 2 & & \\
\hline
\end{tabular}

39 See yet the Appendix of this paper. 
fabrication classes for Roman Age local production (noted as 'Roman' and 'Chilia-Militari'), and the only one being mainly of a fine fabrication is the group of artefacts thought as imports. A 'fine' fabrication is considered for a ceramic paste in which one cannot see, with a naked eye, any intrusions into the clay, or these are very small or sparse; it can be slightly sandy, a bit rough, but very clean. A 'half-fine' fabrication would have visible intrusions, mainly silica, possible others, most visible elements being around one mm, accidentally more; a 'coarse' fabrication imply visible intrusions at sizes around $3 \mathrm{~mm}$, adding to silica opaque minerals, black or dark red, and often crushed sherds; 'very coarse' fabrics are considered for intrusions around $5 \mathrm{~mm}$.

Speaking now only about Roman Age pottery, it is worth mentioning that the crushed sherds from the paste composition are not so rare, occurring in 6 types classified as 'half fine' and 4 types considered as 'coarse', from all three sources ( 4 are imports, 3 Roman pottery of local production and 3 of Chilia-Militari type).$^{40}$ The split of the local made Roman Age pottery, between 'Roman' and 'ChiliaMilitari', made by us all across this paper, will be taken as conventional, discriminating two sets of artefacts made with obvious different firing technologies (but not only). ${ }^{41}$

The pottery from Săpata did not benefit of a complex investigation - petrographic or/and compositional - meant

\footnotetext{
40 The older Roman pottery monograph from southern Romania (POPILIAN 1976) worked with a simplified classification of the fabrication, as 'fine' versus 'coarse' (Rom. 'zgrunţuroasă, approx.. 'rough'), and it is not very helpful for comparisons. A much recent monograph of the Roman pottery from the northern city of Napoca is including an analytical code for fabrication (RUSU-BOLINDET 2007, 60-62), providing a useful comparison sample of data, mainly because it is complemented with a specialised petrographic and chemical expertise, although on a small set of samples (28, see IONESCU/ GHERGARI 2007, 438). This study proves that the so-called 'crushed sherds' (which are in fact grinded) occur in Roman pottery paste from northern Dacia (IONESCU/GHERGARI 2007, 438), mainly for the coarser types (IONESCU/GHERGARI 2007, 448). Crushed sherds were the most usual clay temper within the traditional Dacian pottery, especially on the coarse types (MATEI 2010, 18). For Chilia-Militari culture this degreasing agent is mentioned only for the handmade pottery (BICHIR 1984, 30), but the fabric description for the other classes of pottery is very sketchy). Romanian postRoman archaeology produced only a sort of scientific fairy tale, viewing in the presence of the crushed sherds in the ceramic paste a sort of a secret ethic DNA code (the meaning is shifted from an author to another). The standard description of the handmade pottery, tempered with crushed sherds, occurs unchanged for the extreme western Chernyakhov culture (MITREA/PREDA 1966, 131; see also pages 161-164). The later culture known as IpoteştiCândești was split in a western area (Ipotești) and a eastern one (Cândești) on grounds based mainly on the absence/presence of the crushed sherds (TEODORESCU 1964, 499), with 'ethnic clues' which do not worth mention here. Of course, this is nothing about the presence/absence of the crushed sherds as temper agent, but about the grinding size.

41 See the 'disclaimer' from the end of this paper.
}

to determine its relative place of origin (local versus alien); although necessary in order to classify stuff with scientific bases, that would be an investment - in time first of all maybe more paying on artefacts less fragmented, as those collected from a digging. We proposed anyway such a split between local and foreign pottery, having as departure point the observation that local pottery contains plenty of mica flakes. A second mean of separation were those shapes which could not be of local production, as amphorae, including those containing mica. A third criterion was the fabrication types with a very low occurrence on the site, most likely to be alien. Figure 6 is presenting a selection of typical Roman pottery - first of all, less fragmented sherds - , both locally made or imported, giving the habitual array of shapes and functions, from kitchen pots to flagons, bowls and amphorae. Figure 7 is selecting the most habitual variations of the fabrication types, along Roman wares.

The most striking issue of the systematic survey results might be the large share taken by the so called ChiliaMilitari pottery, known by most of the archaeologists as the cultural expression of the 'Free Dacians' from Muntenia. ${ }^{42}$ The Roman age pottery from Săpata is divided between an alleged local production (52\%), imported matter $(18.81 \%)^{43}$, and Chilia-Militari pottery types (29.19\%). We should get used to, because there isn't any surprise, in fact. Such pottery popped up from our earliest field surveys, in $2012^{44}$, and that ${ }_{42}$ Mostly based on the monograph made by Gh. Bichir (BICHIR 1984).

43 Possibly underestimated, if compared with the recent results from the diggings at the large fort from Băneasa (Teleorman County), where the proportion of imported pottery is larger $(23.62 \%$, see TEODOR 2016c, Table 1). The difference could be yet explained by the distance to the Danube $(23.5$ km for Băneasa, 132 km for Săpata; See TEODOR 2015, 224).

44 TEODOR 2015, 146, 154-155, 162, 166. 

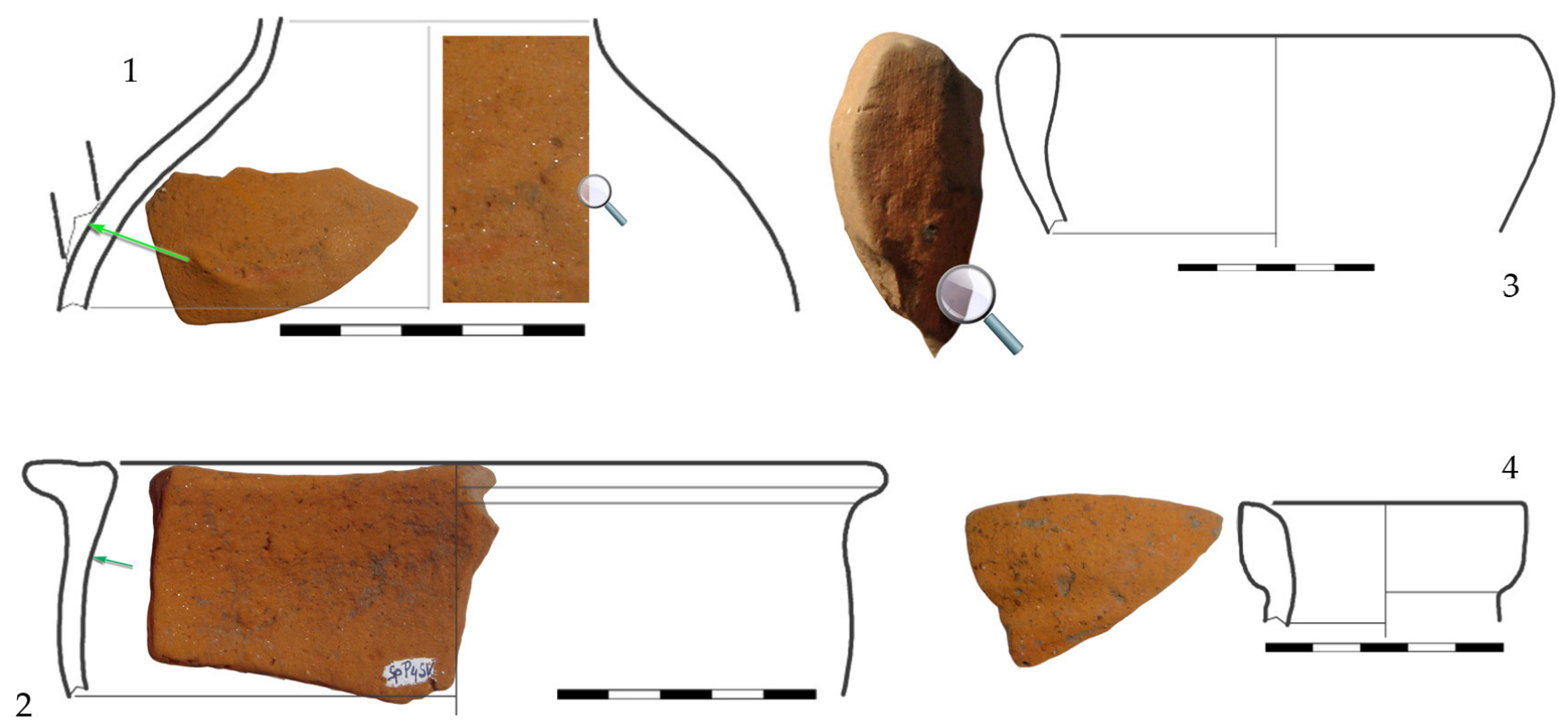

4

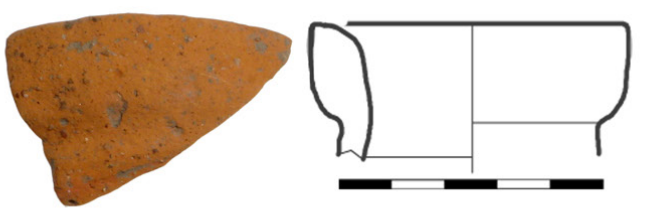

Fig. 7. Most typical variations of fabrication for Roman pottery: half fine, local (1, 2); fine, imported (3); coarse, local (4).

is exactly why this research project has contained a line of activity regarding it, from the very beginning. Systematic surveys done in 2016 confirmed its presence everywhere, not only in the remote positions of the watch-towers, but in the main military sites as well. The percent from Săpata is not even the highest. Chilia-Militari pottery could reach as much as $41 \%$ of all Roman Age pottery at Valea Urlui, 32.3\% at Băneasa, the lowest score being recorded at the double fort from Urlueni, $21.9 \% .^{45}$

As we already published a large study about the main traits of Chilia-Militari pottery, ${ }^{46}$ we will briefly mention here just some of them. The most relevant trait is the grey pottery, following the tradition of the wheel made pottery of the late La Tène Age, relatively fine, frequently burnished (but rarely in decorative patterns), of which were made dinning dishes and liquid containers. ${ }^{47}$ In 'secured' ChiliaMilitari environment, in settlements without connection with the militaries, the grey burnished wares make the majority of the pottery. The old kitchen pottery, handmade and oxidized, is slowly abandoned in favour of Roman kitchen pots, wheel-made, reddish (as a general rule), more or less coarse, sandy; of course, this category cannot be distinguished from the Roman stuff, being the same thing. The traditional, handmade pottery, is occurring less and

\footnotetext{
${ }_{45}$ And probably a similar result at Crâmpoia, in the same middle area of research (between Danube and Argeș River). Those surveys are not yet published in detail, but one can read the Interim report for 2016, the fourth section, on the project website (http://www.limes-transalutanus.ro/rapoarte/ raport_etapa3.html). The relatively large variation (20-40\%) of the pottery ascribed as 'Chilia-Militari' might be due to some regional conditions, as the presence/absence of a certain kind of potters (more or less related to the traditions from the Lower Danube area), or the other way around, by a certain type of 'demand', possibly related to the (ethnic) origin of the garrisons.

46 TEODOR et alii 2015.

47 The burnished pottery is usually connected with the presence of the (Gothic) foederati south of the Danube, beginning with the late fourth century (SWAN 2007, 273), but it is known (in large quantities) north of the Danube as early as the second part of the second century, coming from still older traditions.
}

less, ${ }^{48}$ being on the fringe of disappearance in the late third century, being sometimes made from the same type of clay paste as the red, kitchenware made on the wheel, with or without the old decorative means (fingerprints on the rim or on strips applied on the body, buttons on the shoulder); the same pottery could be found in about the same proportions in 'standard' Roman settlements and cemeteries, from Oltenia $^{49}$. The most popular type of pottery, at least for archaeologists, is the so called Krausengefäß, storage container with triangular (or bilateral) rim section, with flat, wide top, usually decorated with parallel incisions; it can be made both from fine or coarse paste ${ }^{50}$. These shapes developed mainly in the second phase of the culture, i.e. post 320 AD. Another Chilia-Militari thing is the size: this pottery is usually big, larger that the 'Roman' correlatives ${ }^{51}$.

One can see in Figure 8 a selection of drawings made for the less fragmented sherds, displaying almost all the array of shapes, qualities and colours (see the caption). What is obviously missing, this time, are the flagons, which are very characteristic. The bowls are rather large, ranging between 22.2 and $28.6 \mathrm{~cm}$ at the rim and between 9.2 and 12.6 at the bottom. ${ }^{52}$ As about the correspondence on fabrication and colour, for Oltenia there is a relatively straightforward

\footnotetext{
48 In the database there are two handmade sherds (or around $0.5 \%$ ), parts of relatively large pots, made from relatively good quality paste, with sand, but in one case also with crushed sherds, well grinded. In the late third century settlements from Alexandria it takes 5\% from all pottery (TEODOR et alii 2015, 122).

49 POPILIAN 1976, 131-138, There are not given figures, but looking at the catalogue, the pottery considered 'Dacian' take 23 positions, which is less than $2.4 \%$. The real Dacian influence is still much larger, but this is yet to prove.

50 Fine paste as those published by Gh. Bichir (BICHIR 1984, 35), or coarse paste, as were those seen by us (TEODOR et alii 2015, 122).

51 TEODOR et alii 2015, 110-111.

52 Statistics made on Roman bowls from Oltenia shows averages of $20.35 \mathrm{~cm}$ for the rim diameter and $7.32 \mathrm{~cm}$ for the bottom diameter (POPILIAN 1976, 209-211, cat. 761-805). The averages for the bowls from Săpata, considered by us as Chilia Militari pottery, are $26.2 \mathrm{~cm}(\% 29+)$, respectively $10.9 \mathrm{~cm}(\% 49+)$, showing again its superior dimensions, previously stated.
} 

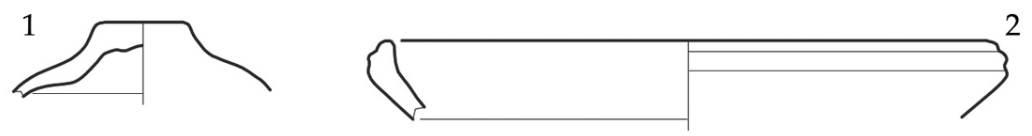

4
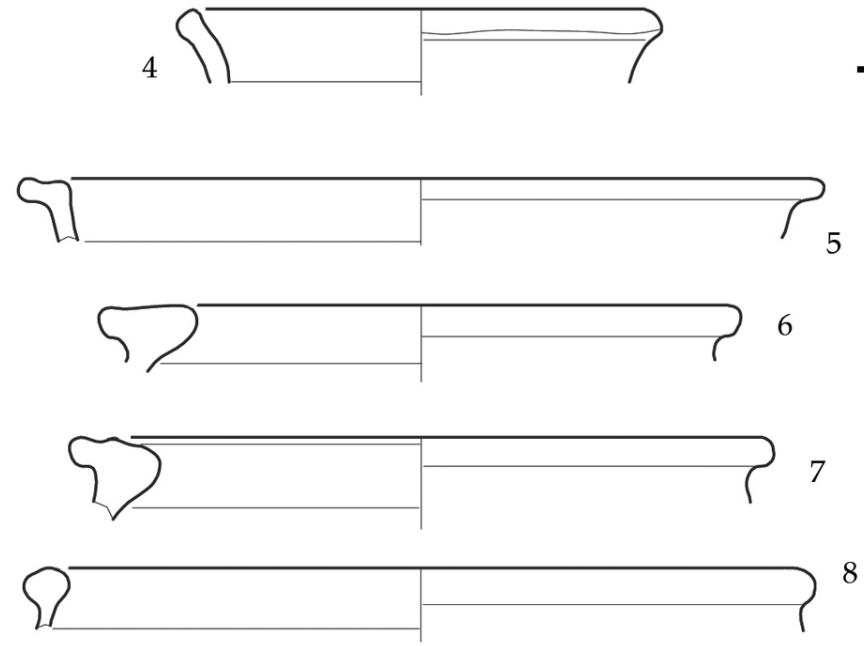

9
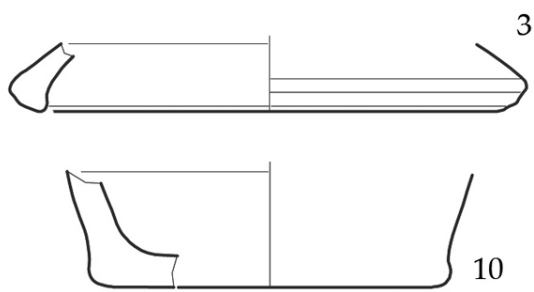

10

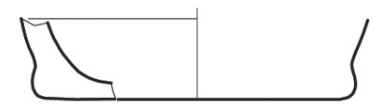

11
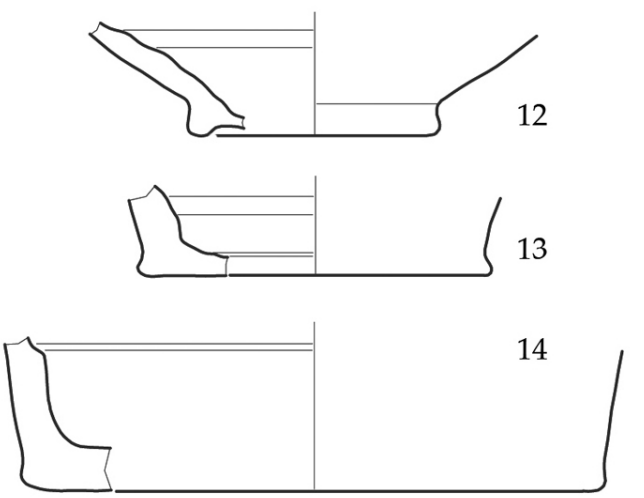

Fig. 8. Chilia Militari type pottery. Lids (1,3), bowls $(2,5,8$ ?, 12?, 13?), jug? (4), kitchen ware (10,11), storage pots $(9,14)$ and Krausengefäß forerunners $(6,7)$; fine fabrication $(2-6,8)$, half fine $(1,7,9-11,13)$, and coarse $(12,14)$; light grey $(1)$, grey $(5,8,13)$, dark grey $(3)$, yellowish grey $(6,12)$, brown with blackish slip (2), reddish yellow $(11,14)$, secondary fired $(4,9,10)$.

relationship: fine bowls are red, almost without exceptions, and coarse bowls are generally grey; ${ }^{53}$ what we have here is the opposite: four fine gray bowls and one coarse bowl, yellowish-gray (se again Fig. 8)

The fragments of the storage containers are rather small, under $30 \mathrm{~cm}$ diameter at the opening; nevertheless, rim sections from Fig. 8/6, 7, although on under calibrated recipients, seem to be the forerunners of the Krausengefüße from the latter third century. One can find fragments of some pots with 'Roman' coloration (Fig. 8/11, 14, reddish yellow), but considered here as Chilia-Militari, due to their morphology (both with profiled foot) and size (Fig. 8/14 is too large for a Roman pot).

Figure 9 brings photos of two very common appearances of Chilia-Militari pottery. One can get sherds completely grey, including the core of the section; most of the time, yet, the core is slightly brown, as the firing would have started in half oxidising conditions. The outer faces of the pots are almost every time darker and in shades of grey, as the firing would have ended in reducing conditions. The finer types were almost always covered with an even finer slip (which in fact makes the difference), as Fig. 9/1.

An interesting question is about the social status of the potters which made Chilia-Militari

53 We counted 31 fine bowls, of which 29 are red, and 14 coarse bowls, of which 11 are gray. stuff. We know that they should be, more or less, some locals. Who was using their products? Why are they not using 'normal', 'Roman' ware? Which is their social status? Are they a sort of 'migrants' allowed at the periphery of the frontier society? Looking back at the Figure 5, one would find not only the overall quantity of Roman Age pottery recovered from each single grid unit, but also the relative ratio for Imports and Chilia-Militari categories. At the glance, both
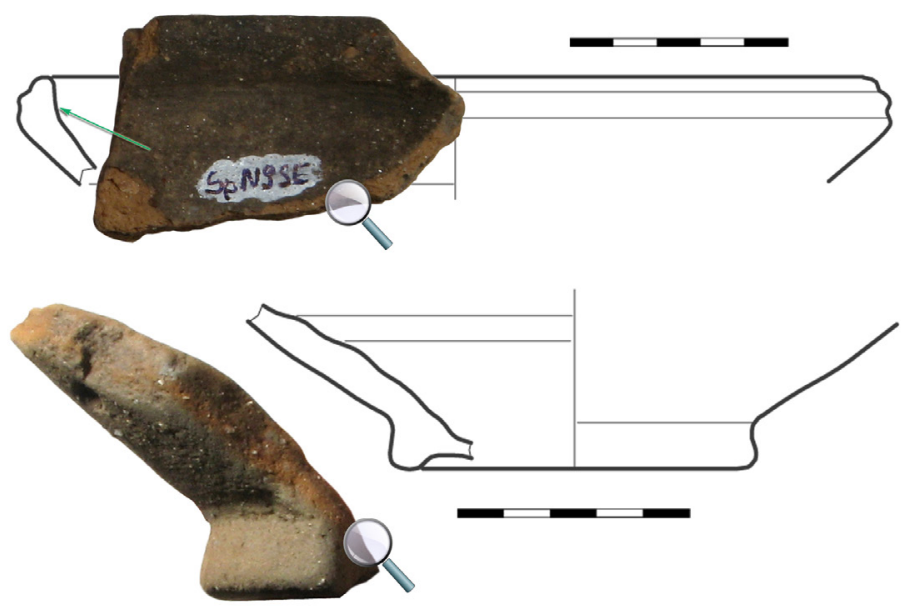

Fig. 9. Examples of typical fabrication for Chilia Militari pottery (see Fig. 8/2, 12). 
imports and Chilia-Militari products are distributed evenly. Of course, proportions made from a scarce inventory could be deceiving, paying too much on hazard. That is why we have selected the grid units with plenty of artefacts, in order to see the ratio of the main classes of pottery (Table 4).

Table 4. The distribution of the main fabrication types of Roman Age pottery in grids with plenty of pottery.

\begin{tabular}{lcccc}
\hline $\begin{array}{l}\text { grid } \\
\text { unit }\end{array}$ & quarter & $\begin{array}{c}\text { Roman Age } \\
\text { total (points) }\end{array}$ & $\begin{array}{c}\text { from which } \\
\text { Chilia-Militari }\end{array}$ & $\begin{array}{c}\text { from which } \\
\text { imports }\end{array}$ \\
\hline L04 & SE & 1181 & $32.68 \%$ & $0.00 \%$ \\
\hline L04 & NW & 942 & $9.77 \%$ & $57.11 \%$ \\
\hline K03 & SW & 778 & $69.79 \%$ & $8.87 \%$ \\
\hline Q09 & NW & 652 & $0.00 \%$ & $0.00 \%$ \\
\hline N09 & SE & 491 & $26.27 \%$ & $0.61 \%$ \\
\hline M04 & NE & 489 & $0.00 \%$ & $100.00 \%$ \\
\hline M12 & SW & 434 & $77.65 \%$ & $0.00 \%$ \\
\hline & overall ratio & $29.19 \%$ & $18.81 \%$ \\
\hline
\end{tabular}

It is now obvious that the users of Chilia-Militari pottery are not 'peripheral' or 'marginal' at all. The first two lines from the Table 4 are for two quarters of the same grid unit, L4, in the closest position of the main Roman monuments, the baths and the small fort. The only places from our systematic survey where Chilia-Militari pottery is missing are the adjacent grid units Q6 and R6, an isolated place, at the fringe of the settlement, with relatively few pottery but relatively many brick fragments.

\section{BRONZE AGE POTTERY}

The total amount of pottery from the Bronze Age fairly equals that of the Roman Age. The distribution is also similar, with some amendments: there are no discoveries on the first terrace, near Cotmeana River and there are just a few discoveries north of the brook. The main part of the settlement is much more bonded to the contour line of 252 $\mathrm{m}$, developing mainly above it, at the edge of the second terrace of Cotmeana (Figure 10). The density of the pottery is also higher in the elevated positions, but the main cluster of discoveries is located at the southern limit of the survey area ${ }^{54}$, immediately below the 252 contour line.

Although not being at all specialists in Bronze Age, we are still going to provide a short description of the main traits of the pottery encountered within the systematic survey in order to place them into the public circuit. The prehistoric ware is obviously divided in two large classes, respectively the common use recipients and the fine, decorated pottery. The first class is made of relatively large recipients (Figure 11), falling in two morphological groups: cauldrons with flat, horizontal handles (perforated or not) on the maximum diameter (Fig. 11/1-4) and opened recipients, with an almost vertical upper body, decorated (or not) with added clay strips and fingerprints. The dimensions are considerable,

54 From that point the altitude is quickly decreasing, to a flat, low land, probably a former fen. A snap survey southward showed that the settlement is ending in that direction. It could continue eastward, where the households of the village Lăngești are laying. the smallest cauldron having the middle diameter of $22 \mathrm{~cm}$ (Fig. 1/1), but the others being quite large (around $40 \mathrm{~cm}$, see Fig. $11 / 2-4)^{55}$; the opened pots are also large, ranging between 30 and $40 \mathrm{~cm}$ at the rim diameter. The quality of the ceramic paste is generally coarse, in average better for the cauldrons and coarser for the opened shapes. The differences are coming not only from the level of sorting the pebbles (very poor in some cases), but also from the presence of a slip made from a better clay, sometimes carefully finished by (discreet) polishing (Figure 12). Disregarding the coarse paste, the sherds are consistent and hard, well fired, although apparently not quite enough, the core being less exposed to the heat ${ }^{56}$. All in all, this pottery seems made for use around the fire, for cooking.

The second class of Bronze Age pottery is meant for social purposes, being tiny, decorated and carefully finished (Figure 13). They are small cups, with a diameter around $5 \mathrm{~cm}$, having small handles on the shoulders (Fig. 13/1), with the surface covered with a type of clay having a totally different composition than the core, turning to black at high firing temperatures. The decoration was done after polishing, by incision, displaying deep grooves organized in different patterns, as stamp-like (Fig.13/1), garlands (Fig. 13/2), or hatched bands (Fig. 13/3). The amount of mica flakes is very low in some cases (as Fig. 13/1), thus they might be 'imports'.

This prehistoric pottery was identified, on the spot, as being connected with Tei Culture, by our colleague from Piteşti, Dragoş Măndescu, statement confirmed later (with moderation) by Sorin Oanță, from the National History Museum. We have explored a well-known synthesis of the matter - made by Valeriu Leahu 25 years ago - in order to understand how our discoveries fit into the greater picture (made yet mainly from discoveries around Bucharest, over $100 \mathrm{~km}$ east of our site). Not great! A first observation is the complete absence of the so called broom decoration, usually encountered in the early and middle phases, ${ }^{57}$ pushing our settlement towards the end of the Tei Culture (phases 4 and 5). From the latest phase of Tei Culture, we were able to identify our 'closed' forms (named here cauldrons) with flat, horizontal handles ${ }^{58}$, the 'opened' shapes with added strips of clay, decorated with fingerprints ${ }^{59}$, although the artefacts from Săpata are far larger. We found also a small cup, barrellike shaped, with flat handles ${ }^{60}$, the hatched bands ${ }^{61}$, and a handle with two attachment points, ${ }^{62}$ similar with our only find of the kind, illustrated in Figure 14. Of course, from a field survey on a settlement of less than three hectares, one cannot expect the whole array of shapes and decorative patterns of a culture running throughout prehistory several

\footnotetext{
55 The restitutions from the Fig. 11 will be taken cum grano salis, because the recovered sherds (from the plowland!) are rather fragmented, the measurement of the diameter being difficult and relative.

${ }^{56}$ A trait due with their great thickness, usually between 9 and $15 \mathrm{~mm}$. A grey core could be also due to a highly organic content of the paste (ORTON/ HUGHES, 2013, 154).

57 Besenstrichverzierung, SCHUSTER et alii 2012, 46, very characteristic for the cultural phase III (there are five at all), but also in the earlier phase (SCHUSTER et alii 2012, 46 with note 26; see also LEAHU 1992, Pl. I/11).

58 LEAHU 1992, Pl. XV/1.

59 LEAHU 1992, Pl. XV/2.

60 LEAHU 1992, Pl. XVI/2.

LEAHU 1992, Pl. XVI/7.

62 LEAHU 1992, Pl. XV/16, 17
} 


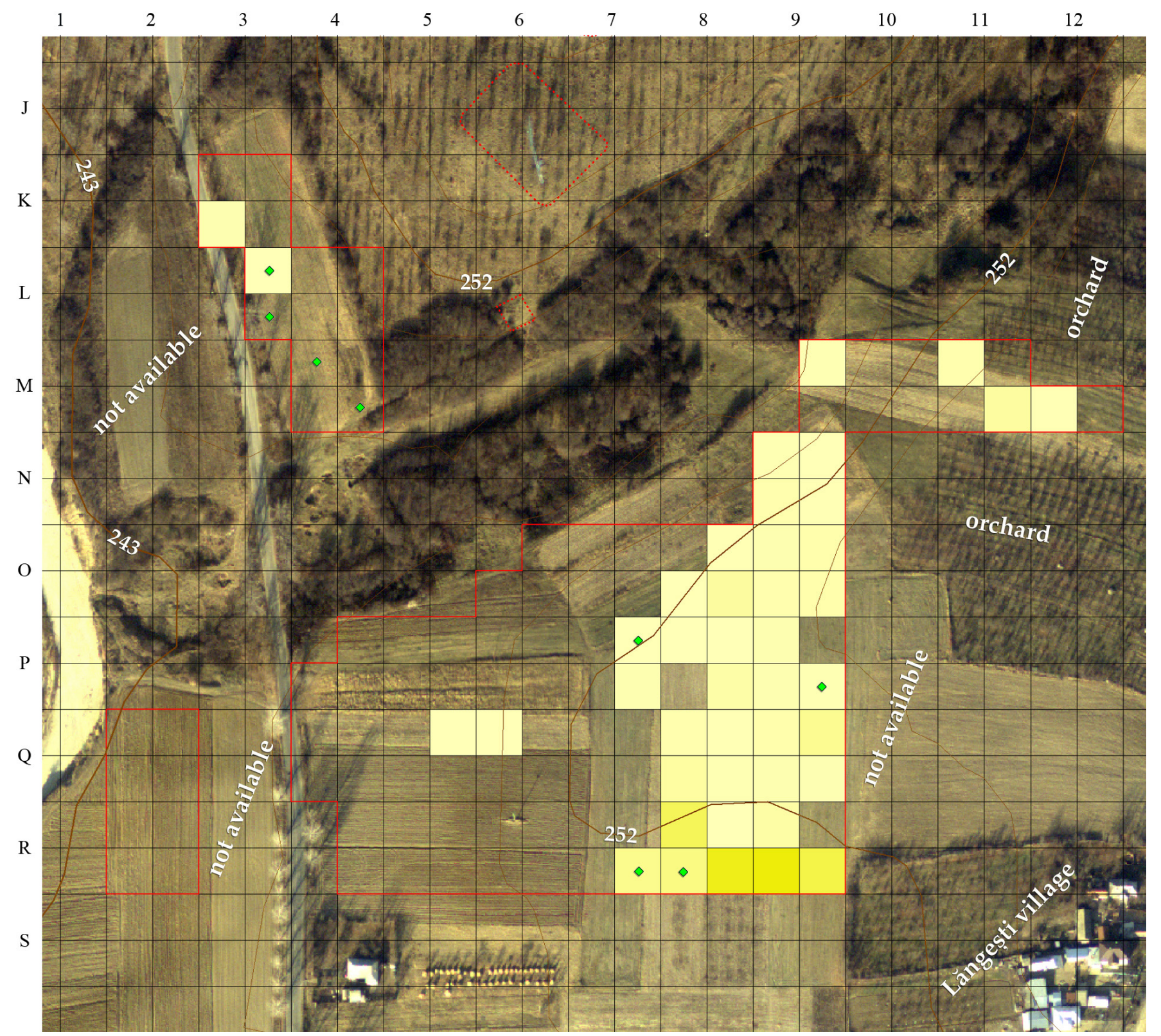

Fig. 10. Results of the systematic survey in the Bronze Age settlement.

Red lines - limits of the research; yellow shades - progressive scale for Bronze Age pottery, from a few (light shades) to many (intense, darker shades); diamonds - flint.

hundreds of years, referring here mainly to the last phase of Tei Culture, the fifth. More than that, one cannot expect to get a fine tuning in cultural assessment for a peripheral geographical area, very poor studied so $\mathrm{far}^{63}$. The exploration of the archaeological map of the Argeş County ${ }^{64}$ shows that our discovery is not in the middle of nowhere, having plotted finds at Silişteni (a few km south of Săpata), Bascov, Valea Ursului and Piteşti, all located around $18 \mathrm{~km}$ towards north and northeast. Searching for details, yet, the knowledge is limited to a bronze axe (Silişteni), a stone one (Bascov) and a few sherds (Piteşti). ${ }^{65}$

Looking back at the Figure 10, one can see the dissimilar distribution of Bronze Age pottery and of those 8 63 As our colleague Sorin Oanţă expressed himself in a personal communication.

${ }_{64}$ MĂNDESCU et alii 2014, 261 with the Map 3.

65 MĂNDESCU et alii 2014, catalogue 17 (Bascov), 356 (Piteşti), 456 (Silişteni), and 567 (Valea Ursului). flint fragments recovered in survey. If $99 \%$ (counted!) of the pottery was found south of the brook, half of the flints were located north of the brook. This cannot be by chance! This is a strong indication that north of the Cetăţii Valley, close to its mouth, was an 'industrial' area, where flint was chopped and fitted into tools. This is interesting, because flint can be worked out anywhere; but the real masters need discretion and hate crowds...

\section{RELIEF ANALYSIS}

Although a regular archaeological research is not possible on the forts, due to the aforementioned vegetation conditions, we made efforts to understand the landscape as much as possible, using all the means at our hand. In the early days of our project (beginning of April 2015) we surveyed the entire site during a double UAV mission, in order to get a high resolution orthophotography, and its pendant - a 

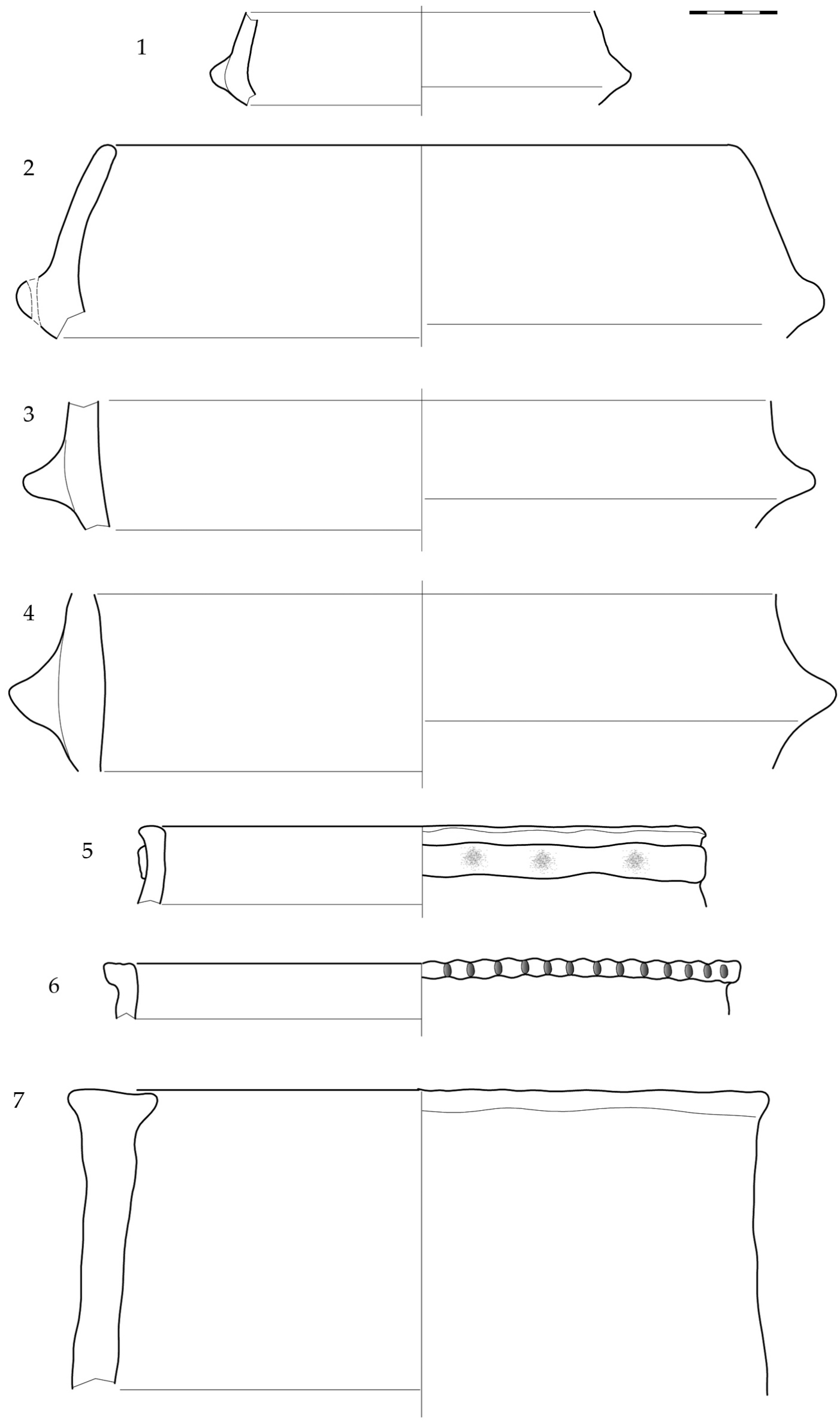

Fig. 11. Bronze Age pottery of common use. Cauldrons with handles on the middle diameter (1-4), open shapes (5-7); half fine $(2)$, coarse $(1,4,5)$, very coarse $(3,6,7)$; grey $(1,2)$, spotted grey $(6)$, yellowish pink (3), yellowish red $(7)$, secondary fired $(4,5)$. 

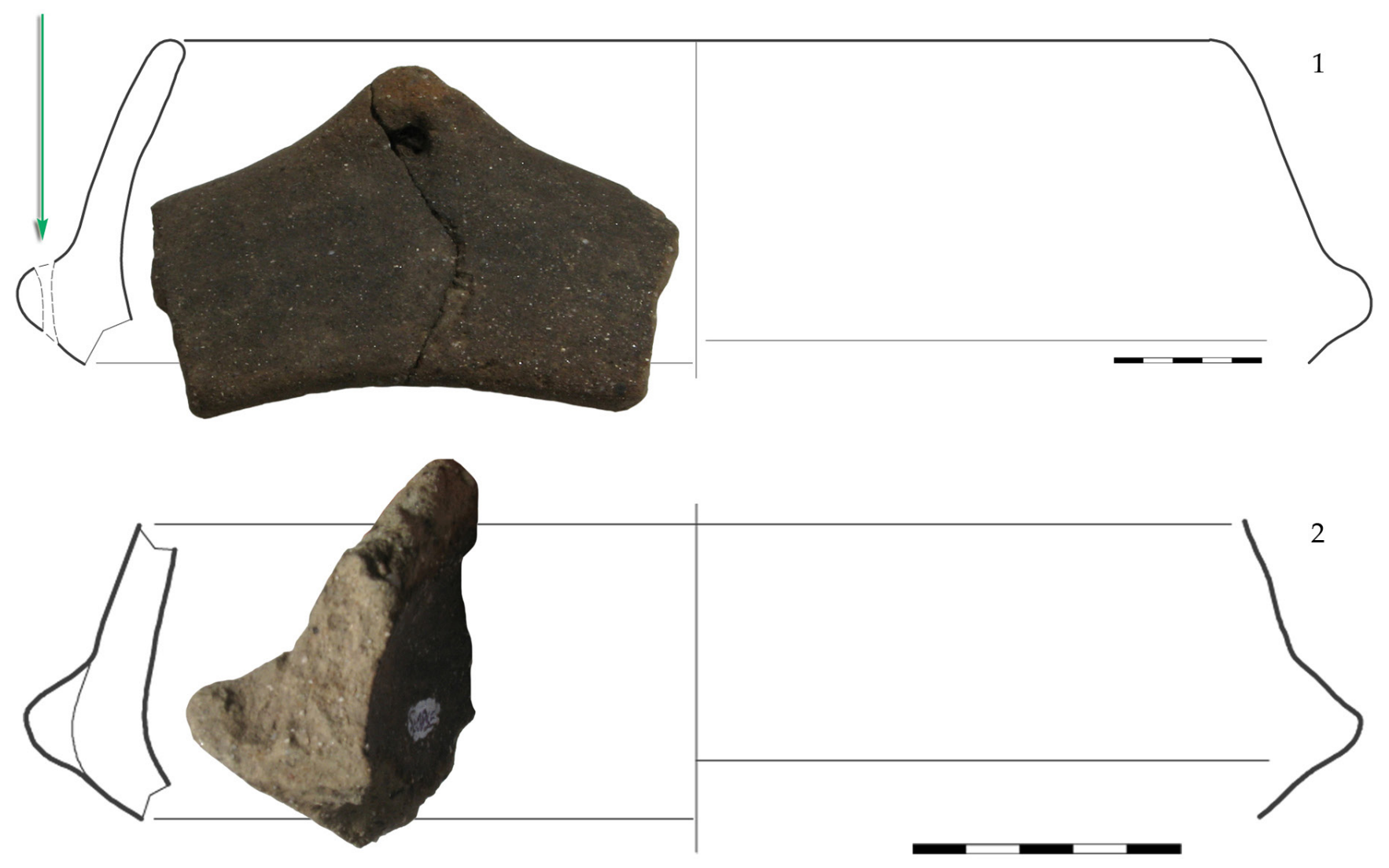

3

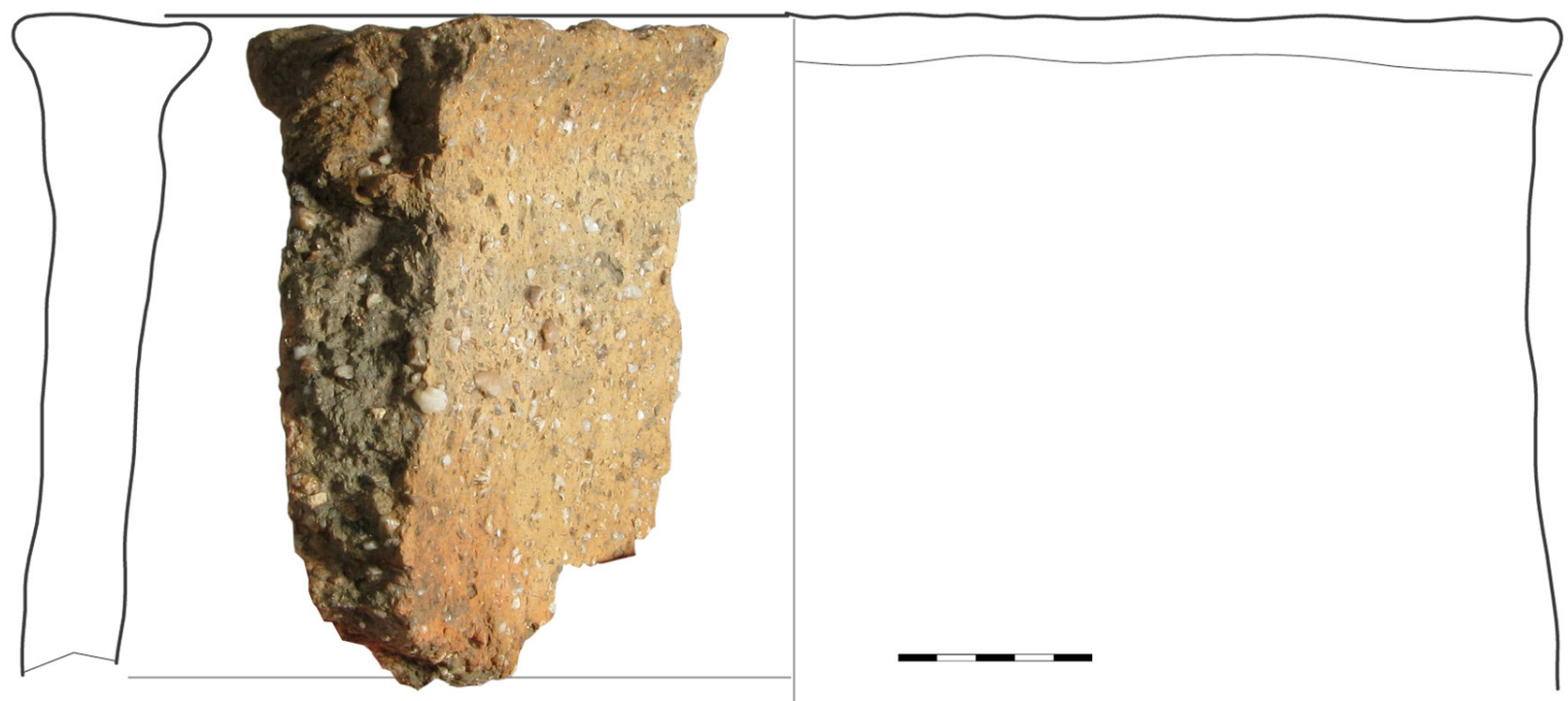

Fig. 12. Bronze Age fabrication of the common use pottery. Examples of half-fine (1), coarse (2) and very coarse fabric (3).

detailed $\mathrm{DEM}^{66}$ (or terrain model). Such a combination of data allowed us to visualise the landscape of the forts and their surroundings in their real shape and colour, and study them from any angle or distance; Figure 15 is only one of the possible renditions. One can better evaluate this way

66 It is a real DEM (digital elevation model), because the height of the forest and of the high bushes were cut off, remaining the approximate level of the foot. Of course, the high vegetation is still visible in photography. the spatial relationship between the forts and the civilian settlement, mainly located across a small valley.

We can now ask questions and seek answers. For instance: why the settlement was located across the valley? The high plateau stretching north to the large fort has enough room for 15-20 houses or so... We think now that the problem was not the space, but the water. From the northern plateau the larger stream of Cotmeana is twice farther; the eastern 

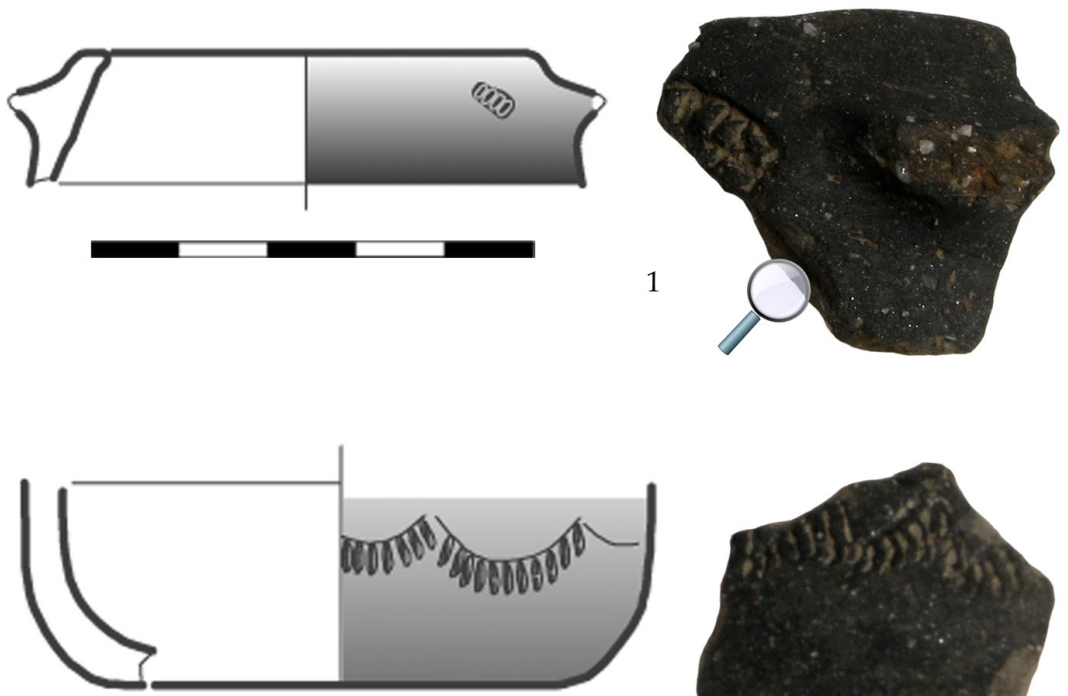

2
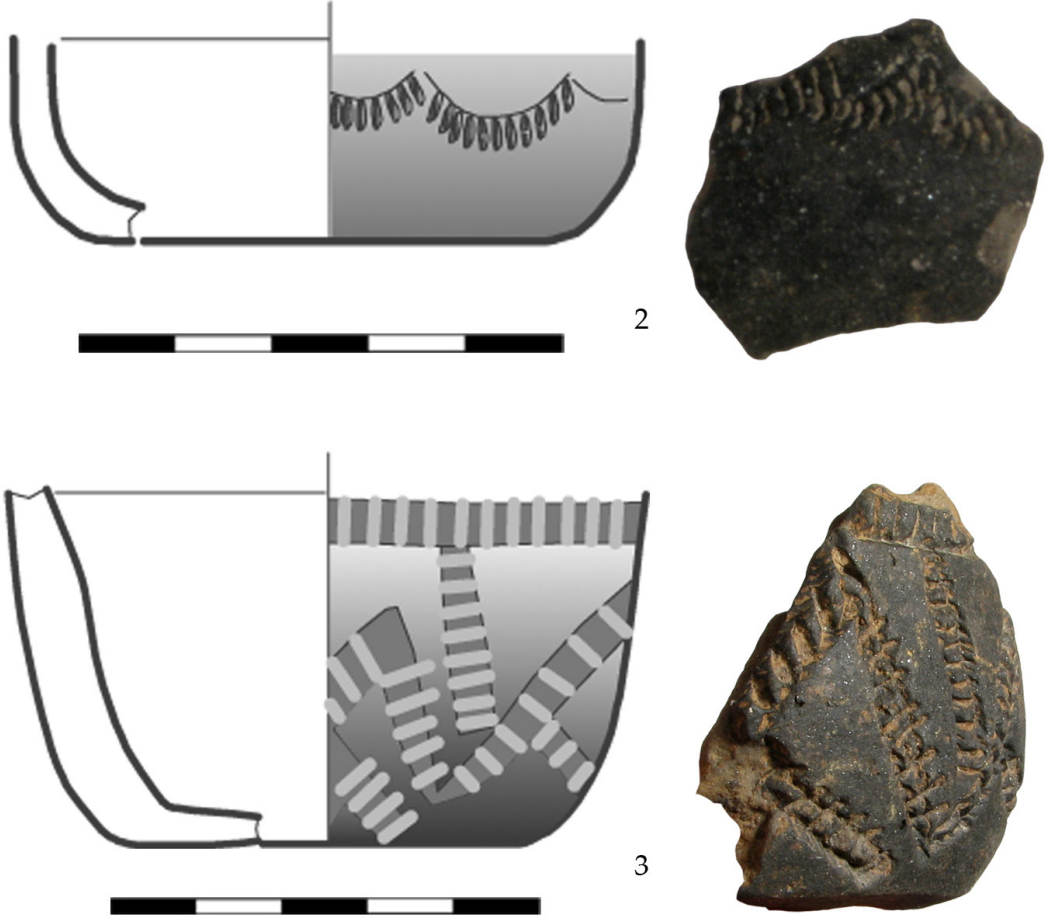

a refuse, and was never used, and we might be, in fact, looking at a production place.

Taking another look at Figure 15 , one may notice a corridor through the high vegetation near the bottom of the valley. That is weird, because nobody made there gardening or alleys to nowhere; this is the natural way in which vegetation grows. It might be a road, connecting the two banks?

Another intriguing detail is the apparent double embankment located east and southeast of the forts, resembling a palisade closing the edge of the plateau. The fact was noticed from the beginning, but a research at the spot left us the impression that those dikelike bumps were related to the settling of the orchard, fitting terraces to easy circulation. We are not that sure any more.

In the 1930s Christescu was writing that the forts were standing on a plough land, and was speaking of several properties. The snapshot he published in the opening of his paper (and reproduced here in Figure 16) is depicting two small embankments crossing the landscape and keeping a certain altitude; they might be the strips of land left unploughed between the properties, but one cannot know how old they were...

We tried then to investigate deeper the story of those ridges, making

Fig. 13. Small Bronze Age pottery, coarse (1), half fine (2) or fine (3).

slope of the plateau is still steeper. Staying on that plateau one would be forced to dig deep fountains. The water pipe fragment (Fig. 6/8) was collected from the southern settlement, from the slope descending to the brook, in the grid unit N9-NE (see Fig. 5 for the exact location). Does it mean that water adduction was necessary in vicus? It is just a possibility. The artefact is, in fact,

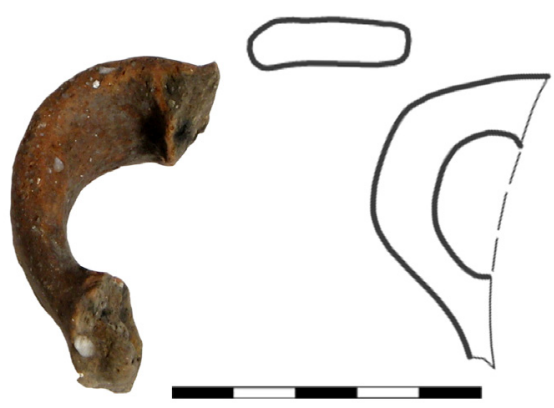

Fig. 14. Bronze Age handle

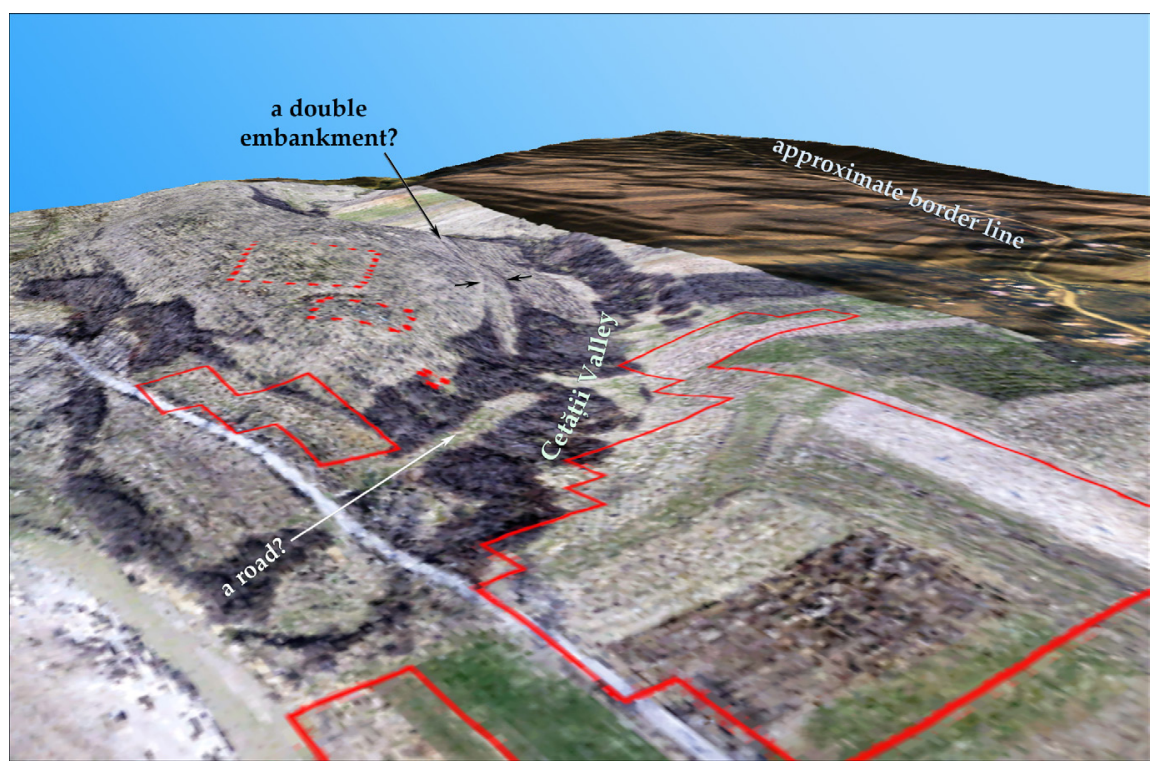

Fig. 15. Foreground: high resolution orthophoto $(0.1 \mathrm{~m})$ and terrain model $(0.2 \mathrm{~m})$; background: middle resolution orthophoto $(0.5 \mathrm{~m})$ and terrain model $(5 \mathrm{~m}$.); red lines: systematic survey perimeters; dotted lines: recorded monuments from the national database. Perspective from southwest, vertical exaggeration 1.9 . 

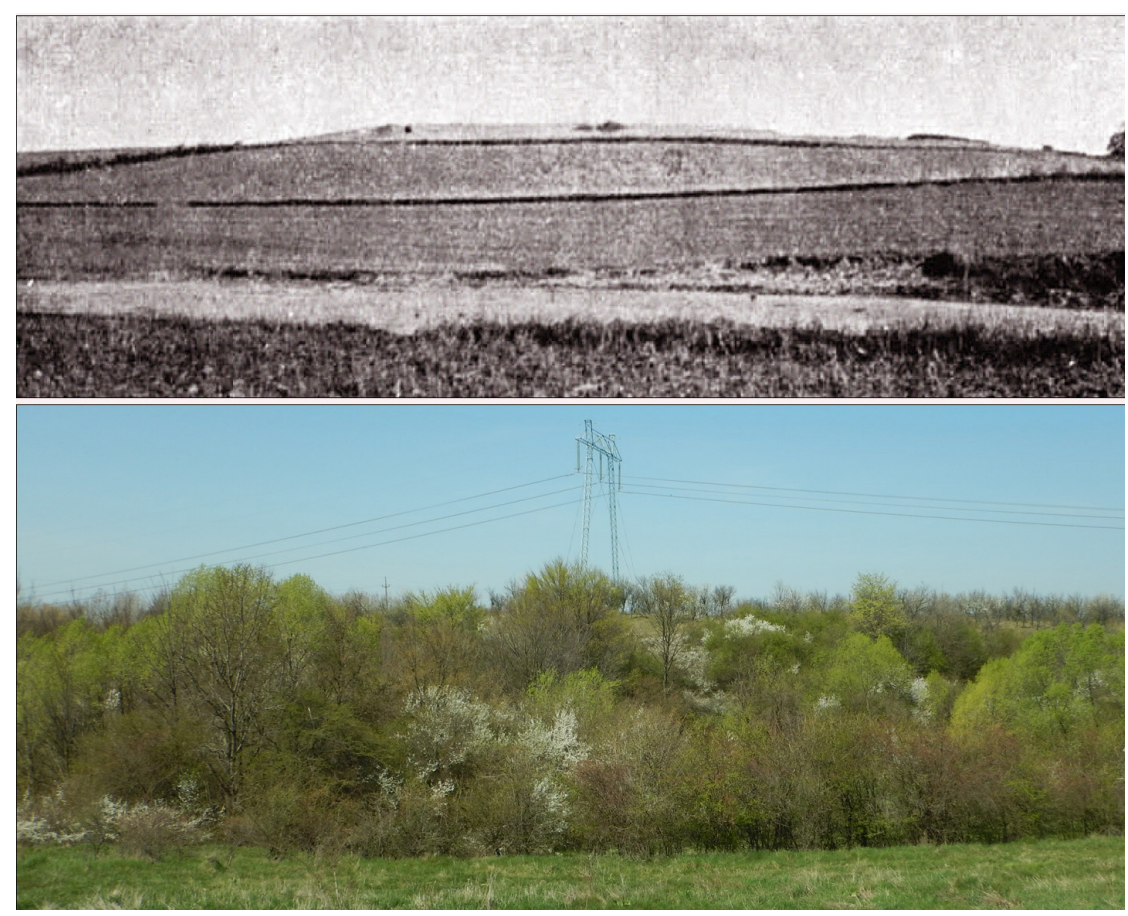

Fig. 16. Up: Photography taken by Christescu (1938, 435, Fig. 1) in 1930, looking northward, to the hill where the forts are located. Down: a snapshot taken in April 2016 from the approximate same position (or perhaps slightly eastward). The high voltage pole is located inside the fortlet (sic).

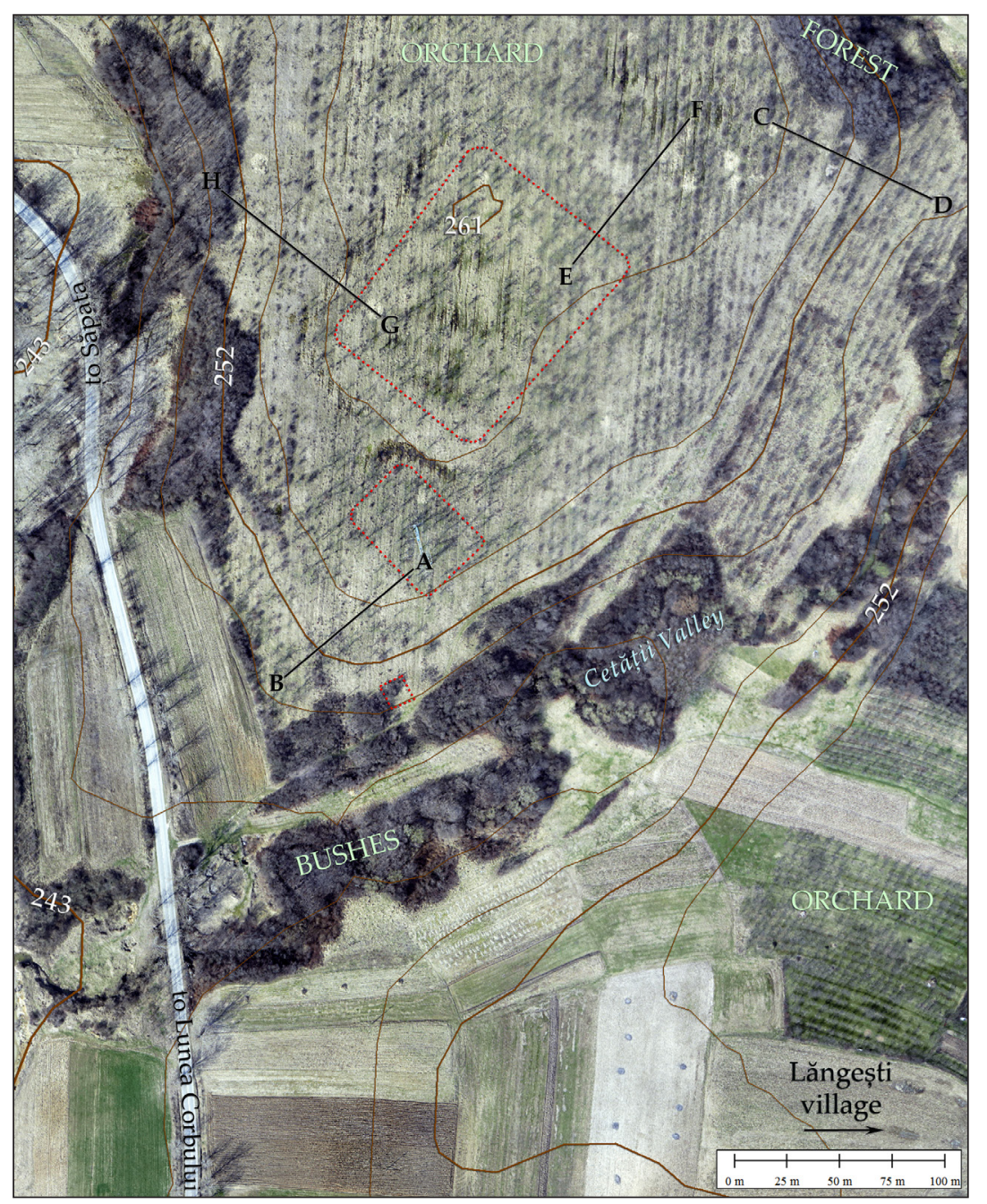

Fig. 17. Orthophoto made via UAV (res. $0.1 \mathrm{~m}$ ), contours as in the Figure $\frac{i}{2}$, and topographical sections on high resolution DEM $(0.2 \mathrm{~m})$, depicted at the Figure 18. a small topographical study, rendered here in Figures 17 and 18. We will start the comments with the topographical section EF, where the ditch can be seen as impressive as it is, $25 \mathrm{~m}$ wide and more than 1.5 deep, seen from the agger; the second ditch cannot be guessed at all, although Tocilescu's plan was depicting it. Very similar observations can be made on the pair section, GH, from the northwestern side. The double embankment from Figure 15 could be retrieved here, in Figure 18, section $C D$, but the situation is far from clear. The upper embankment could be a reinforcement of the terrace's edge, but the lower embankment makes no sense in this respect; the slope didn't get any better (in order to become a 'terrace'), and no agricultural purpose can be advanced. Interesting enough, a similar situation occurs southwest of the fortlet (Fig. 17), where two bumps are also visible (Fig. 18, AB); the upper could be just the outer bench of the defensive ditch (also 25 $\mathrm{m}$ wide). The lower bump is an anthropic alteration of the landscape, because the curve of the hill is broken there. A possible third bump is possible to be asserted $10 \mathrm{~m}$ downhill. Looking back on the Figure 17, this second bump is visible like a more or less continuous embankment, marked by a line of bushes, east of the contour line $252 \mathrm{~m}$. The absolute altitudes of those embankments, from eastern and western sides of the hill, are similar, between 262 and $258 \mathrm{~m}$. To be frank, this is looking more like a military work, than a civilian one.

\section{GEOPHYSICAL ASSESSMENT}

As previously mentioned, the most usual - and effective - geophysical method in the study of Roman forts, which is magnetometry, cannot be employed at Săpata due to the orchard, while a standard archaeological survey remains more or less useless. The only geophysical method at hand was the measuring of the magnetic susceptibility ${ }^{67}$. The method is fast, but its resolution is low; therefore, one can understand that 'something is going on' beneath, but the size and the exact location of the 'anomaly' is not known. The method is based on differences which occur between the natural magnetic properties of the soil and the properties of the anthropic alterations within the landscape, as dams, walls, ovens, tiles, etc. Most of the time,

\footnotetext{
67 Known also as 'kappametry', a name commonly used in informal speech.
} 
A

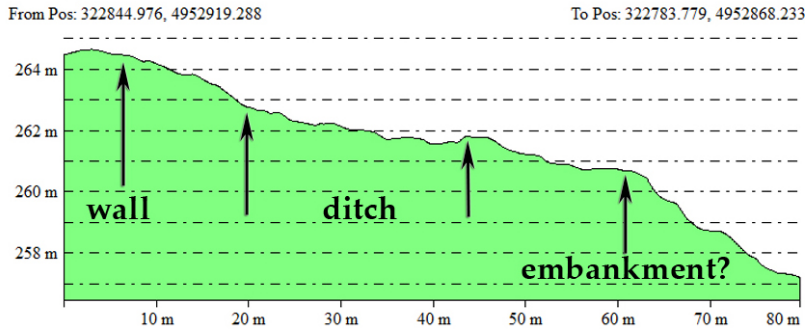

$\mathrm{E}$

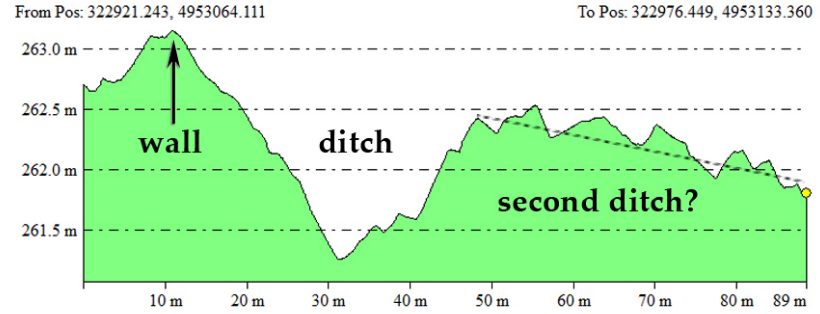

B

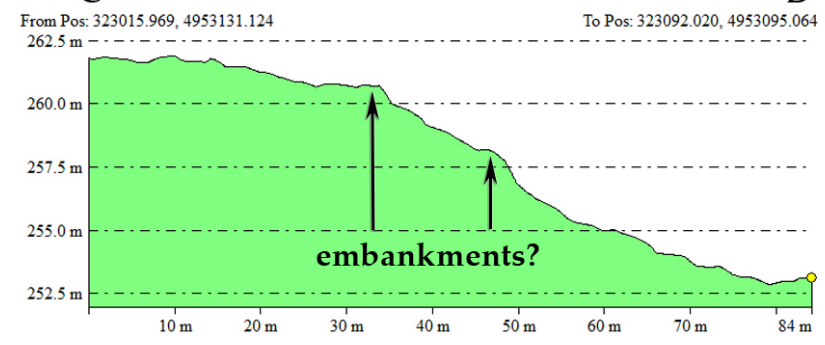

G

$\mathbf{H}$

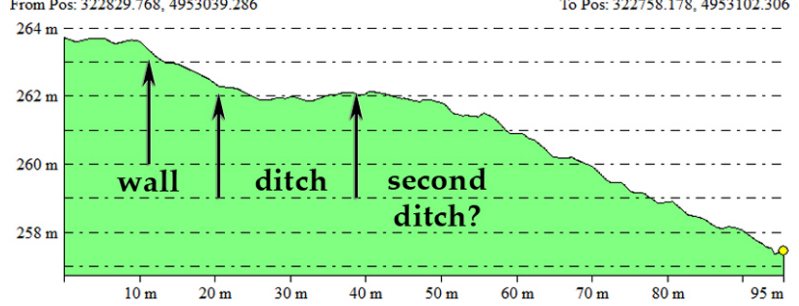

Fig. 18. Topographical sections on the Roman forts from Săpata. See Figure 17 for locations.

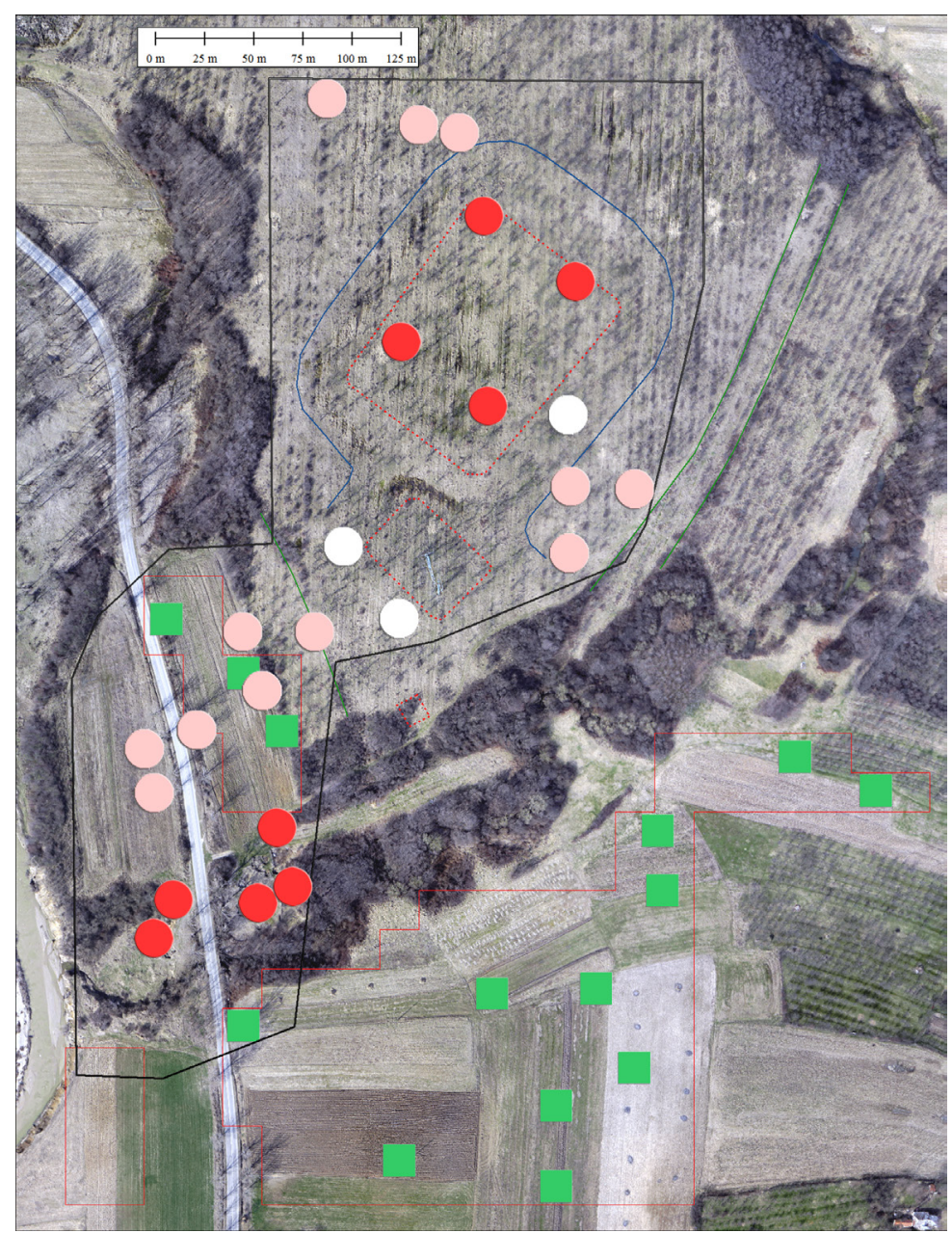

Fig. 19. Overlay of some results. Red polygons: systematic field survey; black polygon: magnetic susceptibility; red dotted lines: the main monuments; blue line: the outer line of the ditch; green lines: embankments; green square: the likely positions of households within the settlement; red circles: high intensity signal (susceptibility); pale pink circles: low intensity signal (susceptibility); white circles: susceptibility signal in neutral locations (the ditch) the natural magnetic susceptibility is low, and the anthropic alterations are highly magnetic, giving a contrast which can reveal buried structures. The best applications of the method are to differentiate between site and non-site, and to reveal areas of higher human activity within a site.

We will not provide here technical details about those measurements, as a special paper is under preparation ${ }^{68}$. We need nonetheless some of those results in order to draw up our conclusions about the archaeological site from Săpata. We have gathered in Figure 19 all the meaningful results of the systematic survey, regarding the Roman settlement, adding a simplified view of the geophysical work, made mainly in the orchard, but also on the lower terrace facing Cotmeana River. The circles are pointing out the places where the signal was stronger than the natural magnetic susceptibility. The view is 'simplified' because there are not rendered the real inputs, the data being split in only two categories: strong contrast (red) and weaker contrast (pale pink pink). ${ }^{69}$

Strong kappametry inputs are recorded where they were expected to pop up, inside the large fort, made out of bricks at least for the enclosure wall..$^{70}$ The only other strong inputs are all located 68 Dan Ştefan, Eugen S. Teodor, Geophysics and Landscape Archaeology. A Large Scale Geophysical Survey on Limes Transalutanus, Proceedings of the Fifth Balkanic Symposium of Archaeometry, 25-29 Sept. 2016, Sinaia, Nona Palincaş et alii (Eds.), Archaeopress.

${ }^{69}$ A third category is a contrast recorded inside the defensive ditch, rendered in white, which is obviously caused by the burned matters rolled into the ditch, and will be disregarded.

70 Widely spoiled by the villagers as early as 1920 s, as the report goes (CHRISTESCU 1938, 437). Interesting to note, he was not been able to find principia, although he tried (idem, 439), and that important building should be made also of bricks. Our 


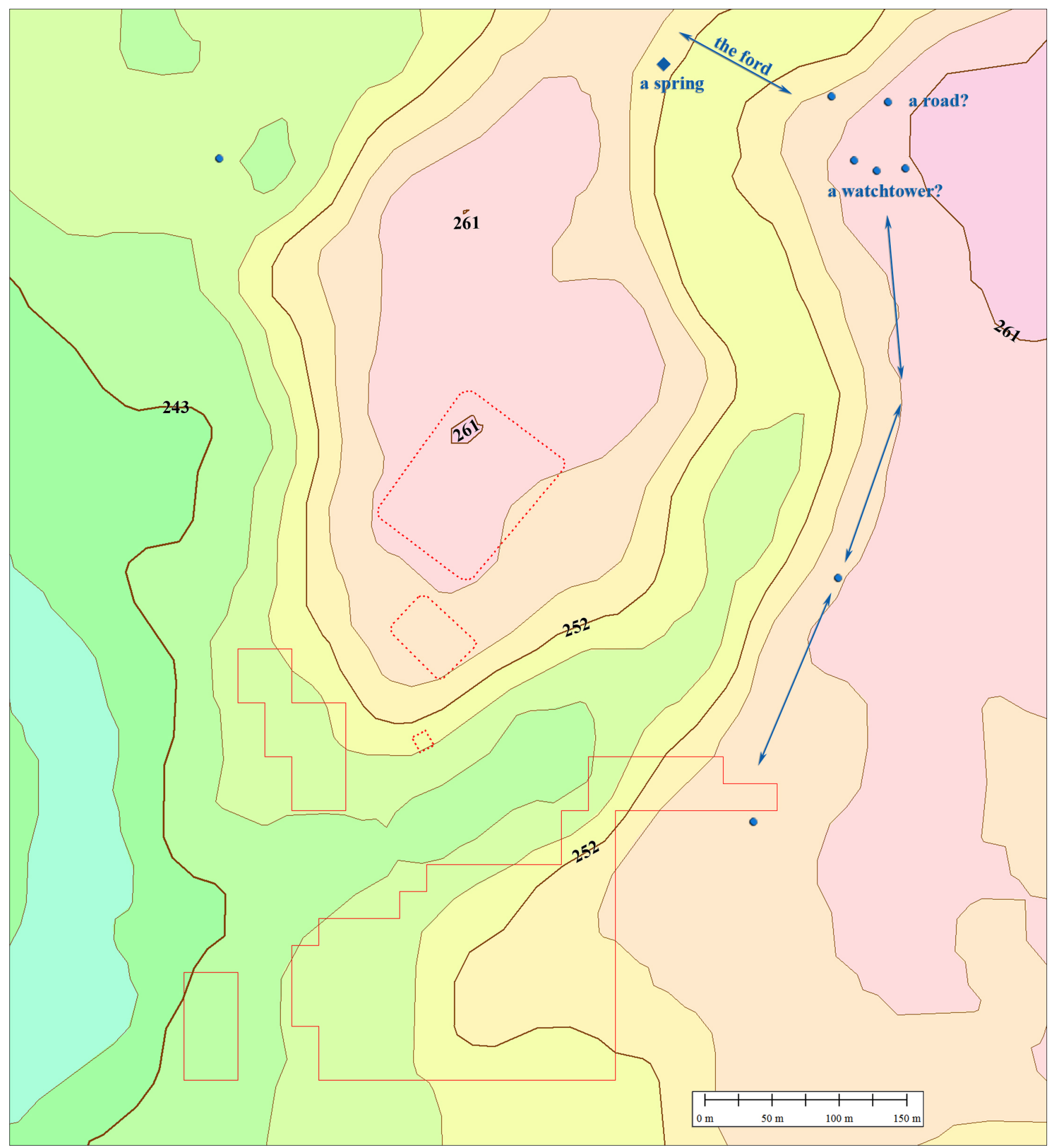

Fig. 20. Linear field survey east and north of the main fort. Circles: isolated discoveries; arrows: the alinement of the survey.

on the northern bank of the brook, near its mouth, which is exactly the area where Tocilescu was indicating 'ruins'. ${ }^{71}$ Those strong signals near the brook are not pinpointing households, but more likely industrial facilities, as brick furnaces or likewise.

geophysical results in the centre of the large fort do not suggest any bricks (left) around. Tests of kappametry made in the area of the Roman baths gave also no relevant result!

71 That area looks today totally deplorable, invaded of bushes and discarded garbage, where not dug for extracting clay (then filled with garbage), used still in vernacular constructions.
Looking now at the weaker signals from Figure 19, it is interesting to spot the small area where the systematic survey and the susceptibility measurements are overlapping. There is no perfect match, but with a good reason: the archaeological survey works with artefacts visible on the surface, and kappametry works with geochemical processes which are happening at depth; due to the slopes (not great in the area, but present), as well as to the ploughing, the artefacts could role over, being collected downhill, which is exactly what happened. 
The upper plateau, around the main fort, looks more or less empty, as the archaeological survey already stated (within the limits of the procedure, in bushy environment). A small group of 'anomalies' (susceptibility peaks) is located between the ditch and the south-eastward embankments of the large fort; ${ }^{72}$ another group is located west of the northern corner. We might think at a statio, or another facility strongly related to the military function.

\section{CLOSING THE CIRCLE}

The area of the systematic survey was limited towards east and northeast by other orchards, in better shape as the large one, from the Roman forts, but also improper for collecting systematic data. Nevertheless, we were concerned about the real extension of the vicus, mainly along the left terrace of Cetății Valley; there are two reasons to search for it there, and not further east: the easy access to the fresh water, and the (customary) proximity to the fort. The orchards are ending at the latitude of the large forts, dealing further with plowland.

The field survey in this sector was performed using four operators, following parallel tracks at $20 \mathrm{~m}$ each, thus covering a strip of land having a width about $80 \mathrm{~m}$, at the very edge of the terrace, which is the main distribution pattern in the studied vicus. The traces of artefacts were extremely poor for a $460 \mathrm{~m}$ path heading northeast (Figure 20), where a cluster of artefacts was identified, including a large stone, a perfectly unusual fact in the field. The location is well suited for a watchtower, having good visibility both eastward, towards the frontier, and to southwest, towards the fort, however no relevant topographic observations were made, the field being perfectly flat. Another $50 \mathrm{~m}$ northwards, a new alinement of (isolated) discoveries suggests the existence of a former road, connecting the frontier zone by the only accessible ford over the valley, where the slopes are not that steep, on the both sides. At that crossing point we found also a spring, pouring out at about $5 \mathrm{~m}$ above the level of the brook. The detail is interesting, showing that the hill of the forts has 72 Unfortunately, the geophysical test could not be developed along the embankment from the south-eastern side (green line at the Figure 19), due to the dense and spiky vegetation, although the photography is suggesting other way around. The orthophotography was made in April 2015, and the geophysical survey in July 2016.

groundwater, and the surface occurrence level, at about 10 meters below the plateau. In comparative terms, the Roman baths are located $10 \mathrm{~m}$ above the brook, and only 5 meters below the plateau, a fact which might suggest that the groundwater is stronger in the lower part of the hill; a good reason to make the main military facilities there.

The fieldwalk on the northern side of the plateau did not provide relevant hints. Although our old hypothesis was that the best route heading to the Albota fort, located towards northeast, would be following the line of the hills, ${ }^{73}$ there are no obvious traces of such a use in Antiquity. Of course, an old route is difficult to spot in a ploughed orchard, but a route implies, near a fort, either some households, either a cemetery. Nothing at all...

Our fieldwalk ended in the meadow located northwest of the hill. Although some small fragments of burned adobe were found, they cannot be dated with simple means. The place is low, between lands even lower, vulnerable to floods, and it is not proper for either a settlement or agriculture, although today it is cultivated.

${ }_{73}$ TEODOR 2015, 92-93. 


\section{ENDING REMARKS}

In the spring and summer 2016 we made a field survey at the Roman site from Săpata, on the frontier known as Limes Transalutanus. We had to deal with two different types of landscape: plowland mainly south of the brook Valea Cetății and a large orchard turned wild, north of the brook. The plowland was accessible for a systematic surface survey, on the clear plots during April, resulting in collected artefacts and data. On most of the northern area the only research resource was the magnetic susceptibility. All the work was supported by orthophotos and digital elevation models made with UAV's missions.

From the systematic archaeological survey, in the open field, we have concluded the existence of about 11 clusters of artefacts south of the brook, and probably 3 north of it, in other words a total of 14 presumptive households of the vicus. From the geophysical work one can add an industrial area, immediately north to the confluence Cotmeana Valea Cetății, other areas on the first terrace north of the brook, and other 7 on the upper plateau, although most of it, around the forts, looks rather empty. All in all, one could count about 25 households and an industrial area. Is that much?

Afortstretching $120 \times 79.5$ mbetween thebattlements, which is a bit smaller than one hectare, cannot host a full size auxiliary unit, ${ }^{74}$ but about half of it, or around $240-250$ militaries, or much less if it is a mounted or mixed (mounted and infantry) numeri. If admitted that the households from the vicus have accommodated the (extended) families of the militaries, there is place only for about one tenth of the members of the garrison, as we can count about around 25 (Figure 21). Admitting that a household would have an average of 5 souls (free and/or slaves), ${ }^{75}$ the population from the vicus would not exceed $125-130$ people, which is about half of the expected population, if not worse. ${ }^{76} \mathrm{In}$ fact, they could have been much many. In vici from Noricum the width of the plots inside the vicus is around $10 \mathrm{~m}$, the length varying between 40 and $50 \mathrm{~m} \cdot{ }^{77}$ Obviously, a fieldwalk cannot detect such a narrow plan pattern. In fact, there are situations in which a cluster of densely cast artefacts is extended on more than one grid unit (see again Fig. 5, grid units K3-NW and K3-SW, N9-NE and N9-SE, P7-NW and P7-NE), but one cannot split them by any objective means.

The distribution of the households seems chaotic at

\footnotetext{
74 In a previous attempt to estimate the size of the garrison from Săpata it has been proven that theoretically it would be possible to host there a full size regiment, with the price of an unusual layout of the fort (TEODOR 2015, 198, Fig. 85). We have to reconsider here that opinion, mainly due to the size of the vicus. The literature is contradictory in the matter. For instance, the fort from Brough-on-Noe, Derbyshire, stretching on only one hectare, could host a mixed regiment (meaning 10 barracks + others, see BIDWELL/ HODGSON 2009, 93-94, with the plan on the Fig. 36). On the other hand, such an esteemed British archaeologist as David Breeze denied the possibility that the fort Bearsden (1.2 ha.) could accommodate a simple cohort, based mainly on extended diggings (BREEZE 2004, 19).

75 SOMMER 1984, 78, note 79.

76 BIRLEY 1973, 15, which was expected a vicus population equivalent with the troops within the fort.

77 ROGERS FLYNT 2005, 145. For the general use of striped houses see also Sommer 2007 (277) for Raetia, or HUNTER 2013 (45) for northern Britain.
}

the first sight ${ }^{78}$. What we know from our own experience, ${ }^{79}$ from similar sites from this Roman frontier, is that the civilian settlements lay on the roads running along the frontier, mainly south of the fort, which the case is for Putineiu and Crâmpoia. The relationship between the fort, the road and the settlement, is yet strongly dependant of the terrain. Whenever the road is coming from south and is pursuing northwards, the layout of the settlement is simple and predictable; this is the case for Urlueni, where there are two relatively large forts, and two settlements on the high terrace, one south of the smaller fort, one northern of the larger fort, proportionally in size. Not all the patterns are so simple, because the spatial relationship between the fort and the frontier is not always simple, and this is the case for Valea Urlui. Both roads, one coming from the frontier line, and the other, connecting the fort with the passage over the valley, are located east of the fort; as a consequence, the main part of the vicus is located eastward, has a compact and mostly round shape.

What we know from the international experience, on far better documented sites, by digging, is that the military vici were developed along the roads driving to the fort, made of long houses, with the shorter sides aligned to the street ${ }^{80}$. Our systematic survey cannot establish the shape of the households, only their relative location, but once sketched the road system their shape and orientation could be reestablished. We have to admit, further, that our survey could not spot every household, as the distances between them (at the Figure 21) are greater than expected.

The picture that came out of the Figure 21 is suggesting a relatively complicated road network, but it seams to respond to certain needs. The main road seems to be that northern one, coming from the frontier, surveyed by a watchtower, approaching the fort through the ford Cetăţii Valley and ending at the north-eastern gate (considered by Christescu as porta praetoria, which now looks right). From this road is detaching southward a branch heading the hard of the vicus, following the edge of the terrace, down to the Cotmeana River bank. In the middle of the vicus there is a crossroad. A road is driving south, and another is driving northwest, on a bridge over Cetățuia Valley, turning west near the baths and reaching the supposed 'industrial area', where a second crossroad could occur. From here, a road is heading up, on the plateau, bypassing eastward the baths,

\footnotetext{
78 The administration of the lands near a fort (probably at the limit of leuga, or $2.2 \mathrm{~km}$ ) is military, which excludes the property rights and suppose the distribution of fairly equal strips of land (ROGERS FLYNT 2005, 143-145; see also SOMMER 1999). This type of genesis does not prevent further transformation of those plots in virtually private properties (SOMMER 1991, 475), mainly for long live settlements (which is not the case in Săpata), but this is quite a different matter. We were interested here only in planimetry: a settlement pattern with uneven distances between the households suggests that some of them are missing of the plan.

79 But not only. Vici made near the gates of the forts: HUNTER 2013, 66, Fig. 1 (Housesteads); BIDWELL/HODGSON 2009, 67-69 (Old Penrith), Slack, West Yorkshire (75-77), Lancaster (84-87), Little Chester (88-90), and along the communication lines, in order to take advantage of the traffic (ROGERS FLYNT 2005, 136; SOMMER 2007, 277), as long as many were half households, half shops (ROGERS FLYNT 2005, 148, 152).

${ }^{80}$ A settlement pattern very well known in many villages from Romania, mainly for those of German origin or influence, mainly in Transylvania. The Saxon colonists arrived here in the late 12 century were coming from southern and western Germany, which are former Roman provinces.
} 
the fortlet and the main fort. A second road diverting from the industrial area is heading north, parallel with the frontier. A similar direction is suggested by the road leaving porta praetoria north-westward.

Finally, the outline of the roads around the forts is simple: a road is connecting the fort to the frontier, another two make side connections, to the south and to the north. Although we are not aware of any closely related settlements, south and north of Săpata military site, they should be somewhere in the landscape. The southern road could drive to the fort from Izbăşeşti, located $11 \mathrm{~km}$ afar (as the crow flies), as a secondary road, different of that following the frontier. We have yet no idea where exactly the northern road drives.

A fourth road is crossing Cotmeana River, heading west, to the inner side of the province. Săpata is located at less than one day travel of three of the most iconic sites of the so-called Chilia-Militari culture: the eponym site Chilia, located $17 \mathrm{~km}$ NW; Scorniceşti, located $22 \mathrm{~km}$ WSW; Coloneşti, where five different sites were identified, the closest being located less than $10 \mathrm{~km} \mathrm{SSW.}{ }^{81}$ All three could play as stations on the Roman road network, making the connection with the Olt River fortifications; Scorniceşti seems the best option, as being located at a standard day travel for heavy loads, ${ }^{82}$ and the closest route to the Olt River. Such proximity explains well enough the bouncing presence of the grey pottery, 'Chilia-Militari', although we are not talking here about the fiction named 'Free Dacians', but about one and the same thing: citizens of the Roman Empire. Much more interesting will be the debate about the distribution of the same pottery far eastward.

In estimating the size of the garrison from Săpata we did not count the fortlet. There are good reasons to do so: first of all, its size allows a maximum of 70 soldiers or so, an amount which doesn't really matter; secondly, we doubt that both forts would have functioned together. The older literature considered the fortlet as being the first made, due to a general 'progressive' concept, that the smaller forts were made first, at the beginning of the second century, when the place was crossed just by a road, not a frontier. ${ }^{83}$ There are many reasons to reject such a projection, but we will stay with the facts, easier to understand. As one can see in Figure 17, the northern side of the ditch closing the fortlet is the most visible part of the entire outline, and this happens because it is the deepest, thus conserving for longer times the moisture, becoming thus a small swamp. All possible cross sections in the area would show the same think, namely that the ditch of the fortlet is cutting the ditch of the larger fort. That means, plainly, that it was cut the last. Therefore, sometimes at the end of the Roman presence on the banks of Cotmeana River, the larger fort was deserted, a much smaller garrison moving in the new fortlet.

81 Coloneşti - Drumul Vechi, see TEODOR et alii 2015, 124 with the Fig. 18, and the list from 132 (no. 36). See also MORINZ 1962; BICHIR 1980, 1986.

82 Lionel CASSON $(1994,189)$ was giving the next standard distances depending of the means: $25-30$ miles $(37-45 \mathrm{~km})$ for wagons and 12-15 miles $(18-22 \mathrm{~km})$ for pedestrians. Such stations should be convenient both for mounted (for changing horses) or pedestrians, as for the last the distance between Limes Transalutanus and Olt River (where a second line fortresses is standing) is too large for one day travel.

83 BOGDAN CĂTĂNICIU 1997, 95, as a general statement; see also pages 96-101 (about the pair forts from Urlueni).
Although the main job undertaken during our survey was to establish the limits and the density of the vicus, we have to stress also the complicated issue of the Chilia-Militari pottery. The distinction operated between the local Roman production and Chilia-Militari stuff is not a straightforward one, being rather a convention. We are inheriting an archaeological tradition in which the Roman province and the contemporary culture of the autochthonous ('Free Dacians'), stretching partially on the Roman soil (sic), were rather parallel worlds, studied by different specialists, never crossing each others way. The definitions used by both parts are painfully fuzzy. Gheorghe Bichir was writing about the coarse, kitchenware pottery made within the Chilia-Militari environment, making up to one third of all pottery in the villages from the third century, that it 'bespeaks about the strong Roman influence' ${ }^{\text {' } 4}$. At his turn, Gheorghe Popilian, introducing the locally made Roman pottery from Dacia Inferior, was speaking about a double acculturation: a Roman influence on the Dacian pottery before the conquest (mainly for flagons' morphology) $)^{85}$, but also about a 'Dacian legacy' on provincial pottery, especially for the kitchenware, which is predominantly grey ${ }^{86}$. Therefore we do not have solid criteria splitting the archaeological artefacts falling in 'Roman provincial' and 'Chilia-Militari' categories, looking much as a dead end. Interesting to note, Bichir was considering the kitchenware as being basically Roman, but Popilian has detected a strong 'Dacian legacy' for the same. Obviously, the kitchen is the best place for mixing things...

There are several things which need a thoughtful reconsideration. For instance: are we seeing the colours in the same way? The first author of this paper made diggings at the Roman fort from Răcari (Dolj County) for eight campaigns, working mainly with third century pottery (around 90\%); the kitchen ware from that fort is not grey, but rather a (dark) greyish-brown. It is the same thing? The same question works for the kitchen ware production south of the Danube, for which similar, greyish pots were being made after the Marcomanic wars ${ }^{87}$ One could note also that the military and ethnic composition in Dacia Inferior and Moesia Inferior are quite kindred..$^{88}$

In order to understand which is the difference between the Roman provincial pottery used west and east of the Lower Olt River, we need to go beyond the grossly division red (oxidised) versus grey (reduced) pottery, as between certain types of containers the ratios are dis-balanced. For instance, only $4 \%$ of the one handled flagons from Oltenia are grey $^{89}$, but no less than $72 \%$ of the handles pots are the same ${ }^{90} \ldots$ As we tried to show previously, on the case of the bowls, a tight statistic comparison could give much more certitude. We need further statistics on the morphology of the rims and bottoms, usable also for broken pottery. This 84 BICHIR 1984, 37.

85 POPILIAN 1976, 83. See also his considerations about some types of jars, as 7 and 8, classified as Roman but coming from the Dacian tradition (POPILIAN 1976, 88).

86 POPILIAN 1976, 86.

SULTOV 1985, 24; KLENINA 2002, 697. In a previous book, Sultov published colour Pl.s, from which just a few coarse pots are grey (SULTOV 1976, 105, 107, 110).

88 WEAVERDYCK 2016, 85-86.

89 POPILIAN 1976, 185-193, cat. 418-531, 4 out of 113 artefacts.

90 POPILIAN 1976, 178-182, cat. 315-369, 39 from 54 artefacts. 
is a long run ahead and, of course, it is to do on pottery recovered from a digging, not from a fieldwalk.

To conclude, our distinction between the local, Roman pottery, and Chilia-Militari pottery, is not yet based on solid, scientific grounds, but on personal experience working with both categories of artefacts. And yes, we could be wrong, but not that much... You do have, along Limes Transalutanus, an array of shapes and shades which is different from the Roman pottery made Cisalutanus, located only 20-40 km westward.

\section{ACKNOWLEDGEMENT}

All research undertaken to fulfil this paper was founded by the Ministry of Education, through UEFISCDI, on the project no. PN-II-PT-PCCA-2013-4-0759.

\section{APPENDIX \\ Fabrication types at Săpata site}

Fabrication types were numbered and described as they have appeared. The types are reordered here, grouped on alleged origin and character of the artefact.

\section{Local manufacturing, "Roman type" fabrication}

\begin{tabular}{|c|c|}
\hline 1 & $\begin{array}{l}\text { sandy, relatively fine (silica }<2 \mathrm{~mm} \text { ), small amount of mica, } \\
\text { not homogenous, incomplete kneading }\end{array}$ \\
\hline 2 & $\begin{array}{l}\text { sandy, relatively fine, lots of mica, crushed sherds added } \\
\text { (low frequency, up to } 3 \mathrm{~mm} \text { ) }\end{array}$ \\
\hline 3 & $\begin{array}{l}\text { sandy, relatively fine, lots of mica flakes; silica up to } 1 \mathrm{~mm} \text {; } \\
\text { sparse black inclusions }\end{array}$ \\
\hline 4 & sandy, coarse (silica $<3 \mathrm{~mm}$ ), lots of mica flakes \\
\hline 16 & variant for \#1, having lots of black inclusions \\
\hline 23 & sandy, silica <2 mm, sparse mica (possibly not local) \\
\hline 25 & sandy, coarse (inclusions up to $5 \mathrm{~mm}$ ), mica, iron oxides \\
\hline 27 & fine sand with red iron oxides, unusually porous \\
\hline 29 & $\begin{array}{l}\text { small amount of fine sand, small amount of mica, very } \\
\text { sparse inclusions }\end{array}$ \\
\hline 30 & $\begin{array}{l}\text { sandy, low presence of silica, but unusual large amount of } \\
\text { blackish minerals }\end{array}$ \\
\hline 31 & $\begin{array}{l}\text { moderately sandy, half fine (silica up to } 2 \mathrm{~mm} \text { ), plenty of } \\
\text { very small mica flakes }\end{array}$ \\
\hline 32 & variant for \#27, without visible pores (with naked eye) \\
\hline 42 & $\begin{array}{l}\text { variant for \#2, but the crushed sherds are far better grinded, } \\
\text { all visible inclusions below } 1 \mathrm{~mm}\end{array}$ \\
\hline 48 & as \#42, but coarser (all inclusions $<2 \mathrm{~mm}$ ) \\
\hline 50 & as \#23, adding relatively frequent blackish pigments \\
\hline 56 & $\begin{array}{l}\text { sand relatively abundant, silica }<2 \mathrm{~mm} \text {, relatively plenty of } \\
\text { mica flakes }\end{array}$ \\
\hline 59 & sandy, well sorted, silica <2 mm, plenty of mica \\
\hline 60 & as \#2, but the crushed sherds are frequent \\
\hline
\end{tabular}

\section{Roman Age, imports (not local production)}

\begin{tabular}{|c|c|}
\hline 9 & sandy, fine, no mica, light brown, with tiny yellowish spots \\
\hline 10 & $\begin{array}{l}\text { sandy, fine, mica flakes extremely fine, no visible inclusions, } \\
\text { yellowish-red }\end{array}$ \\
\hline 11 & as \#10, but no mica flakes \\
\hline 15 & sandy, well sorted ( $<1 \mathrm{~mm})$, no mica; red \\
\hline 17 & $\begin{array}{l}\text { similar with \#3 (local), but no mica flakes, finer, no visible } \\
\text { inclusions; external slip at the same colour (yellowish-red) }\end{array}$ \\
\hline 22 & $\begin{array}{l}\text { sandy, well sorted, half-fine, mica flakes, tiny black } \\
\text { inclusions, pores }<1 \mathrm{~mm}\end{array}$ \\
\hline 24 & $\begin{array}{l}\text { sandy, half-fine, inclusions }<1 \mathrm{~mm} \text {, mica flakes especially on } \\
\text { the surface }\end{array}$ \\
\hline 26 & $\begin{array}{l}\text { fine, dusty touch (low sand content), with very fine mica } \\
\text { flakes }\end{array}$ \\
\hline 36 & sandy, silica $<2 \mathrm{~mm}$, black oxides, porous, no mica flakes \\
\hline 41 & as \#26, but no mica \\
\hline 49 & $\begin{array}{l}\text { sandy and relatively fine, very low (but present) mica, many } \\
\text { blackish spots }\end{array}$ \\
\hline
\end{tabular}


51 very fine, slippery surface, discreet mica flakes, no other visible inclusions; fawn

53 sandy but fine, no mica, silica $<1 \mathrm{~mm}$, black small minerals $(<1 \mathrm{~mm})$

sandy, relatively coarse, silica rare but up to $2 \mathrm{~mm}$, blackish and opaque mineral $<3 \mathrm{~mm}$ (frequent), mica flakes (rare), crushed sherds (rare); yellowish-pink

58 sandy, relatively fine but rough touch, black and opaque inclusions $<1 \mathrm{~mm}$; pale yellowish-pink

\section{Chilia-Military pottery type}

\begin{tabular}{|c|c|}
\hline 7 & $\begin{array}{l}\text { sandy, well kneaded, silica }<2 \mathrm{~mm} \text {, plenty of mica, black } \\
\text { oxide; dense; reduced firing }\end{array}$ \\
\hline 13 & similar with \#7, no oxide \\
\hline 14 & $\begin{array}{l}\text { nearly excessive sandy but fine, well sorted }(<1 \mathrm{~mm}) \text { and } \\
\text { well fired (usually reduced, variant slightly oxidised) }\end{array}$ \\
\hline 19 & $\begin{array}{l}\text { sandy but very well sorted ( }>1 \mathrm{~mm}) \text {, traces of iron oxides } \\
\text { and plenty of mica flakes (especially on surfaces) }\end{array}$ \\
\hline 20 & $\begin{array}{l}\text { sandy, coarse, plenty of mica flakes, uncertain type of firing, } \\
\text { mainly reduced }\end{array}$ \\
\hline 33 & $\begin{array}{l}\text { local clay, well sorted, plenty of mica, with crushed sherds } \\
\text { (large and frequent) }\end{array}$ \\
\hline 34 & variant to \#33, less well sorted (silica <2) \\
\hline 35 & as \#33, but lesser crushed sherds \\
\hline 40 & as \#19, but no oxides visible \\
\hline 47 & as \#20, with crushed sherds added \\
\hline 54 & $\begin{array}{l}\text { sandy, well sorted, plenty of mica (especially on surfaces), } \\
\text { iron oxides, probably very fine crushed sherds; darker slip }\end{array}$ \\
\hline 57 & $\begin{array}{l}\text { sandy, slightly excessive, silica }<1 \mathrm{~mm} \text { (accidentally } 2 \mathrm{~mm} \text { ), } \\
\text { small amount of mica /variant of \#14/91 }\end{array}$ \\
\hline 61 & $\begin{array}{l}\text { sandy but consistent, silica }<2 \mathrm{~mm} \text {, but } \mathrm{NO} \text { mica flakes } \\
\text { (although obviously local!) }^{92}\end{array}$ \\
\hline
\end{tabular}

\section{Bronze Age}

6 sandy, coarse (silica $<3 \mathrm{~mm}$ ), with many darker spots (a soft matter), well fired, mostly reduced

8 half coarse (silica $<2 \mathrm{~mm}$ ), iron oxide (sparse), consistent,

8 well fired, with bright red on surface and grey core ${ }^{93}$

12 very coarse (silica up to $5 \mathrm{~mm}$ ) but well fired and consistent highly unusual: relatively fine, with very small mica flakes,

18 traces of iron oxide; the slip contains crushed sherds, added probably with decorative intensions

21 relatively fine, well sorted, plenty of mica, consistent, oxi-

21 dised surfaces, grey core (as \#8)

sandy, half fine, with lenticular dark spots; reduced firing,

37 blackish slip, well finished (very similar to Chilia-Militari pottery)

\begin{tabular}{ll}
\hline $\mathbf{3 8}$ & as \#37, but worst sorted (silica $<2 \mathrm{~mm}$ ) \\
\hline $\mathbf{3 9}$ & as \#6, without oxide \\
\hline $\mathbf{4 3}$ & $\begin{array}{l}\text { sandy but fine, without visible inclusions (mica very } \\
\text { discreet) }\end{array}$ \\
\hline $\mathbf{4 4}$ & $\begin{array}{l}\text { sandy, relatively coarse (silica <2), mica flakes, lots of fine } \\
\text { crushed sherds; half oxidised firing, bright shades }\end{array}$ \\
\hline
\end{tabular}

\begin{tabular}{ll}
\hline 45 & $\begin{array}{l}\text { sandy, lot of mica, average sorting }(<2 \mathrm{~mm}) \text {, plenty of } \\
\text { crushed sherds and iron oxides }\end{array}$ \\
\hline $46 \quad \begin{array}{l}\text { well sorted, mica flakes, iron oxides, visible vegetal marks; } \\
\text { fine, slippery surface }\end{array}$ \\
\hline
\end{tabular}

\section{Middle Age or Modern}

\begin{tabular}{ll}
\hline $\mathbf{5}$ & half fine, with plenty of mica (mainly on the surface) \\
\hline $\mathbf{5 2}$ & $\begin{array}{l}\text { more sandy (as in Roman Age), with iron oxides and crushed } \\
\text { sherds (sic! surely medieval) }\end{array}$ \\
\hline
\end{tabular}

note that Middle Age pottery could have more than two types

\section{Frequency of the fabrication types}

Where

B = Bronze Age

$\mathbf{C M}=$ Chilia Militari

IND = not determined

$\mathbf{R}=$ Roman (local production)

$\mathbf{R I}=$ imports of the Roman Age

\begin{tabular}{|c|c|c|c|c|c|c|c|c|c|c|c|}
\hline type & B & B? & $\mathrm{CM}$ & CM? & IND & M & M? & $\mathbf{R}$ & $\mathbf{R} ?$ & $\mathbf{R I}$ & RI? \\
\hline & 5 & & 2 & & 60 & 3 & & 2 & & & \\
\hline 1 & & & & 1 & & & & 5 & 1 & & \\
\hline 2 & & & 1 & & 1 & & & 13 & & & \\
\hline 3 & & 1 & & & & & & 59 & 1 & & \\
\hline 4 & 1 & & & & & & & 8 & 2 & & \\
\hline 5 & & & & & & 77 & 2 & 1 & & & \\
\hline 6 & 12 & 2 & & & & & & & & & \\
\hline 7 & & & 18 & 2 & & & & & & & \\
\hline 8 & 12 & 2 & & & & & & & & & \\
\hline 9 & & & & & & & & 1 & & 4 & \\
\hline 10 & & & & & & & & & & 8 & \\
\hline 11 & & & & & & & & & & 6 & \\
\hline 12 & 62 & & & & & & & & & & \\
\hline 13 & & & 7 & 1 & & & & & & & \\
\hline 14 & & & 16 & & & & & & & & \\
\hline 15 & & & & & & & & & & 4 & \\
\hline 16 & & & & & & & & 2 & & 1 & \\
\hline 17 & & & & & & & & & & 2 & \\
\hline 18 & & 1 & & & & & & & & & \\
\hline 19 & & & 23 & & & & & & & & \\
\hline 20 & & & 3 & 1 & & & & & & & \\
\hline 21 & 3 & & & & 1 & & & & & & \\
\hline 22 & 1 & & & & & & & & & 7 & 1 \\
\hline 23 & & & & & & & & 14 & & & \\
\hline 24 & & & & & & & & & & 13 & \\
\hline 25 & & & & & & & & 5 & & & \\
\hline
\end{tabular}




\begin{tabular}{|c|c|c|c|c|c|c|c|c|c|c|c|}
\hline type & B & B? & $\mathrm{CM}$ & CM? & IND & $\mathbf{M}$ & M? & $\mathbf{R}$ & $\mathbf{R} ?$ & $\mathbf{R I}$ & RI? \\
\hline 26 & & & & & & & & & & 3 & \\
\hline 27 & & & & & & & & 3 & & & \\
\hline 28 & & 1 & & & & & & & & & \\
\hline 29 & & & & & & & & 4 & & & \\
\hline 30 & & & & & & & & 2 & & & \\
\hline 31 & & & & & & & & 4 & & & \\
\hline 32 & & & & & & & & 4 & & & \\
\hline 33 & & & 8 & 1 & & & & & & & \\
\hline 34 & & & 9 & & & & & & & & \\
\hline 35 & & & 8 & & & & & & & & \\
\hline 36 & & & & & & & & & & 2 & \\
\hline 37 & 5 & & & & & & & & & & \\
\hline 38 & 3 & & & & & & & & & & \\
\hline 39 & 1 & & & & & & & & & & \\
\hline 40 & & & 4 & & & & & & & & \\
\hline 41 & & & & & & & & & & 1 & \\
\hline 42 & & & & & & & & 3 & & & \\
\hline 43 & 7 & & & & & & & & & & \\
\hline 44 & 2 & & & & & & & & & & \\
\hline 45 & 5 & 1 & & & & & & & & & \\
\hline 46 & & 1 & & & & & & & & & \\
\hline 47 & & & & & & & & 2 & & & \\
\hline 48 & 1 & & & & & & & & & & \\
\hline 49 & & & & & & & & & & 2 & \\
\hline 50 & & & & & & & & 2 & & & \\
\hline 51 & & & & & & & & & & 1 & \\
\hline 52 & & & & & & 1 & & & & & \\
\hline 53 & & & & & & & & & & 2 & \\
\hline 54 & & & 5 & & & & & & & & \\
\hline 55 & & & & & & & & & & 1 & \\
\hline 56 & & & & & & & & & 4 & & \\
\hline 57 & & & 1 & & & & & & & & \\
\hline 58 & & & & & & & & & & 1 & \\
\hline 59 & & & & & & & & 6 & & & \\
\hline 60 & & & & & & & & 1 & & & \\
\hline 61 & & & 1 & & & & & & & & \\
\hline
\end{tabular}

\section{REFERENCES}

\section{BICHIR 1980}

Bichir, Gh., Săpăturile de la Colonești-Guești (jud. Olt), Materiale ș Cercetări Arheologice 14, 261-266.

BICHIR 1984

Bichir, Gh., Geto-dacii din Muntenia în epocă romană (Bucureşti: Ed. Academiei).

BICHIR 1986

Bichir, Gh., Vestigii ale geto-dacilor din epoca romană la Scornicești (jud. Olt), Thraco-Dacica 7, 1-2, 112-128.

\section{BIDWELL/HODGSON 2009}

Bidwell, P./Hodgson, N., The Roman Army in Northern England (Newcastle upon Tyne: Arbeia Society).

\section{BIRLEY 1973}

Birley, R. E., Civilians on the Roman Frontier (Newcastleupon-Tyne: Graham).

BOGDAN CĂTANICIU 1981

Bogdan Cătăniciu, I., Evolution of the System of Defence Works in Roman Dacia, British Archaeological Reports, International Series 116 (Oxford, Archaeopress).

BOGDAN CĂTĂNICIU 1997

Bogdan Cătăniciu, I., Muntenia în sistemul defensiv al Imperiului roman, sec. I-III p. Chr. (Alexandria: Muzeul Judeţean Teleorman).

\section{BREEZE 2004}

Breeze, D., The Antonine Wall. The North-West Frontier of the Roman Empire. Proposed as a World Heritage Site (Edinburgh: Historic Scotland).

\section{BURNHAM/WACHTER 1990}

Burnham, C. B./Wachter, J., The Small Towns of Roman Britain, Berkeley (Los Angeles: University of California Press).

\section{CAMPBELL 1978}

Campbell, B., The Marriage of Soldiers under the Empire, The Journal of Roman Studies 68, 153-166.

\section{CANTACUZINO 1945}

Cantacuzino, Gh., Le grand camp romain situé de la commune Baneasa (dép. de Teleorman), Dacia IX-X, 19411944 (1945), 441-472.

\section{CASSON 1994}

Casson, L., Travel in the Ancient World (Baltimore: Johns Hopkins University Press)

\section{CHRISTESCU 1934}

Christescu, V., Le trésor de monnaies de Săpata de Jos et la date du limes romain de la Valachie, Istros I, 73-80.

\section{CHRISTESCU 1938}

Christescu, V., Le <castellum> romain de Săpata-de-Jos, Dacia V-VI, 1935-1936 (1938), 435-447.

DIMA 2012

Dima, M., Aurei din timpul domniei lui Gordian al III-lea descoperiți pe limesul transalutan, Studii și Cercetări de Numismatică 15, 133-140.

\section{DREWETT 1999}

Drewett, P. L., Field Archaeology: An introduction (London: UCL Press \& Taylor \& Francis)

EVANS REES 2013

Evans Rees, B., MA Assignment: Landscape Archaeology Module. Fieldwalking, Community Landscape Archaeology Survey Project website, retrieved 28 Jan 2017 on claspweb. org.uk/wp-content/uploads/2013/05/field_walking.pdf.

\section{HUNTER 2013}

Hunter, J., Housing in the Military Vici of Northern Britain, dissertation draf, King's College London, https://kcl. academia.edu/JamesHunter (accessed 20 Jan 2017).

IONESCU/GHERGARI 2007

Ionescu, C./Ghergari, L., Caracteristici mineralogice şi 
petrografice ale ceramicii romane din Napoca. In: RusuBolindeţ, V., Ceramica romană de la Napoca (Cluj-Napoca: Mega), 434-462.

IUGA 1942

Iuga, V. G., Un om vrednic: Pamfil Polonic, Natura 31, 6, 224-227.

KLENINA 2002

Klenina, E., Some remarks about the Roman and early Byzantine pottery from Novae (Moesia Inferior). In: Freeman, P./ Bennett, J./ Fiema, Z. T./ Hoffmann, B. (eds.), Limes XVIII. Proceedings of the XVIIIth International Congress of Roman Frontier Studies held in Amman, Jordan (September 2000) II, British Archaeological Reports, International Series (supplementary) 1084 (Oxford: Archaeopress), 695-703.

KOOISTRA ET ALII 2013

Kooistra, L.I./Dinter, M. van/Dütting, M. K./Rijn, P. van/ Cavallo, C., Could the local population of the Lower Rhine delta supply the Roman army? Part 1: The archaeological and historical framework, Journal of Archaeology in the Low Countries 4, 5-23.

LEAHU 1992

Leahu, V., Date și considerații noi cu privire la periodizarea culturii Tei, Cercetări Arheologice 9, 1992, 62-72.

MATEI 2010

Matei, S., Ceramica geto-dacică din nord-estul Munteniei. $\mathrm{PhD}$. Thesis manuscript (Bucharest: Bucharest University).

\section{MĂNDESCU/DUMITRESCU/PĂDURARU 2014}

Măndescu, D.,/Dumitrescu, I.,/Păduraru, M., Repertoriul arheologic al judeţului Argeş (Brăila: Istros)

MITREA/PREDA 1966

Mitrea, B./Preda, C., Necropolele din secolul al IV-lea e.n. în Muntenia (Bucureşti: Ed. Academiei).

MORINZ 1962

Morinz, S., Săpăturile de la Chilia (r. Vedea, reg. Argeș), Materiale și Cercetări Arheologice 8, 513-519.

PETAC 2011

Petac, E. Aspects de la circulation monétaire en Dacia romaine (106-275 apr. J.C.) (Wetteren: Moneta).

PETOLESCU 2010

Petolescu, C., Dacia, un mileniu de istorie (București: Ed. Academiei).

POPILIAN 1976

Popilian, Gh., Ceramica romană din Oltenia (Craiova: Scrisul românesc)

ORTON/HUGHES 2013

Orton, C./Hughes, M., Pottery in Archaeology. Cambridge Manuals in Archaeology (New York : Cambridge University Press).

ROGERS FLYNT 2005

Rogers Flynt, Sh., The Military Vici of Noricum. PhD. Thesis manuscript (University of Missouri-Columbia).

RUSU-BOLINDEŢ 2007

Rusu-Bolindeţ, V., Ceramica romană de la Napoca. Contribuţii la studiul ceramice din Dacia romană (Cluj-Napoca: Mega).

SCHUCHHARDT 1885

Schuchhardt, C., Wälle und Chausseen im südlichen und östlichen Dacien, Archäologisch-epigraphische Mitteilungen aus Oesterreich-Ungarn 9, 202-232.

SCHUSTER/NEGRU/HĂLMĂGEANU 2012

Schuster, C./Negru, M./Hălmăgeanu, C., Notă cu privire la un lot de materiale Tei III de la București-Militari-Câmpul Boja, sectorul C. Campaniile 2008 și 2012, Buridava 10, 2012, 42-54.

SOMMER 1984

Sommer, S., The Military Vici of Roman Britain: Aspects of their Origins, their Location and Layout, Adiminstration,
Function, and End, British Archaeological Reports 129 (Oxford: Archaeopress).

\section{SOMMER 1991}

Sommer, S., Life beyond the ditches: Housing and Planning of the Military Vici in the Upper Germany and Raetia. In: Maxfield, V. A./Dobson, M. J., Roman frontier studies. Proceedings of the XVth International Congress of Roman Frontier Studies (Exeter: University of Exeter Press), 472-476.

\section{SOMMER 1999}

Sommer, S., From conquered territory to Roman province: recent discoveries and debate on the Roman occupation of SW Germany. In: Creighthon, J., et alii (eds.), Roman Germany: studies in cultural interaction. Journal of Roman Archaeology, Supplementary Series 32 (Portsmouth: Rhode Island), 161-198.

\section{SOMMER 2007}

Sommer, S., Kastellvici am Raetischen Donaulimes Aufbau und Funktion, Vorträge des 26. Niederbayerischen Archäologentages 14, 253-284.

\section{SULTOV 1976}

Sultov, B., Ancient Pottery Centres in Moesia Inferior (Sofia: Sofia Press).

\section{SULTOV 1985}

Sultov, B.,Ceramic production on the territory of Nicopolis ad Istrum (II ${ }^{\text {nd }}-I V^{\text {th }}$ century) (Sofia: Terra Antiqua Balcanica).

\section{SWAN 2007}

Swan, V. G., Ditchin (Bulgaria): Interpreting the Ceramic Evidence in its Wider Context. In: Poulter, A. (ed.), The Transition to Late Antiquity, on the Danube and Beyond. Proceedings of the British Academy 141 (Oxford: Oxford University Press), 251-280.

TARTARON 2003

Tartaron, Th. F., The Archaeological Survey: Sampling Strategies and Field Methods. In: Wiseman, J./ Zachos, K. L. (eds.), Landscape Archaeology in Southern Epirus, Greece. 1. The Nikopolis project (Princeton: American School of Classical Studies at Athens), 23-45.

\section{TEODOR 2015}

Teodor, E. S., The Invisible Giant: Limes Transalutanus. An overview south of Argeș River (Târgoviște: Cetatea de Scaun).

\section{TEODOR 2016a}

Teodor, E. S., How Effective is the Law's protection? Limes Transalutanus case. In: Musteață, S. (ed.), Tendințe curente în protecția patrimoniului arheologic din România și Republica Moldova (Chișinău-Iași: ARC), 31-46.

TEODOR 2016b

Teodor, E. S., De pază pe Limes Transalutanus. Despre turnurile de pe segmentul sudic. In: Teodor, E. S. (ed.), Arheologia peisajului și frontiera romană (Târgoviște: Cetatea de Scaun), 67-96.

TEODOR 2016c

Teodor, E. S., New Archaeological Researches at the Roman Fort from Băneasa (Teleorman County), Cercetări Arheologice,23 (forthcoming).

\section{TEODOR 2016d}

Teodor, E. S., Frontiera văzută de sus. Cercetări pe sectorul argeșean al Limes Transalutanus, In: Teodor, E. S. (ed.), Arheologia peisajului și frontiera romană (Târgoviște: Cetatea de Scaun), 27-56

TEODOR 2017

Teodor, E. S., Watch and Alert along Limes Transalutanus. The quest for watching towers on the southern sector. In: Sommer, C. S./Matešić, S. (eds.), Proceedings of the 23rd International Limes Congress, Ingolstadt 2015 (forthcoming). TEODOR/BĂDESCU/HAITĂ 2015

Teodor, E. S./Bădescu, A./Haită, C., One Hundred Sherds. 
Chilia-Militari reloaded. Alexandria pottery case, Journal of Ancient History and Archaeology 2/4, 90-135.

TEODOR/ȘTEFAN 2014

Teodor, E. S./Ștefan, M. Landscape Archaeology along Limes Transalutanus, Journal of Ancient History and Archaeology 1/3, 31-43.

TEODORESCU 1964

Teodorescu, V., Despre cultura Ipoteşti-Cândeşti în lumina cercetărilor arheologice din nord-estul Munteniei, Studii şi Cercetări de Istorie Veche 15, 485-503.

\section{WEAVERDYCK 2016}

Weaverdyck, Eli J. S., Isolation or integration? A Spacial Analytical Approach to the Loca Impact of the Roman Army on the Northern Frontier. PhD. Thesis manuscript (Berkeley: University of California). 